\title{
Remarks on the Philosophical Reflection of Fate in the Writings of Seneca
}

\section{Christoph Schubert}

\section{(2) OpenEdition \\ 1 Journals}

\section{Electronic version}

URL: http://journals.openedition.org/mythos/486

DOI: $10.4000 /$ mythos. 486

ISSN: 2037-7746

\section{Publisher}

Salvatore Sciascia Editore

\section{Printed version}

Date of publication: 1 December 2016

Number of pages: 125-155

ISBN: 978-88-8241-476-4

ISSN: $1972-2516$

\section{Electronic reference}

Christoph Schubert, "Remarks on the Philosophical Reflection of Fate in the Writings of Seneca ", Mythos [Online], 10 | 2016, Online since 24 September 2019, connection on 15 November 2019. URL http://journals.openedition.org/mythos/486; DOI : 10.4000/mythos.486 


\section{Remarks on the Philosophical Reflection of Fate in the Writings of Seneca}

\section{Christoph Schubert}

\section{Abstract}

The assertion of strict determinism was considered as to be a crucial part of the Stoic doctrine. Most other philosophical schools of the ancient world ridiculed or attacked it, whereas the Stoics consistently defended it. Nonetheless Seneca, the most eminent Roman Stoic, never presented a systematic description of what he thought fatum to be. The article offers a selection of the philosopher's most important remarks about fate in a number of single works (Naturales Quaestiones, De providentia, De vita beata, Consolatio ad Helviam, Epistulae morales, Epigrams, Tragedies) placing them in the respective line of argument and considering their scope. It can be shown that behind these selective remarks there exists a highly consistent doctrine of fatum in perfect accordance with the Stoic mainstream. However, Seneca does not deal anywhere with the weak points of the concept, but introduces it almost everywhere as a self-evident basis for his reasoning. His primary interest lies in the psychological problems with acceptance of fatum and in the practical handling of its apparent lack of transparency and predictability.

\section{Keywords} Seneca - Stoicism • fate - necessity - free will

Schlüsselworte Seneca - Stoa

\section{Zusammenfassung}

Die Annahme eines strengen Determinismus gilt als ein unverwechselbares Kernstück der stoischen Lehre, das von anderen philosophischen Schulen der Antike gerne ironisiert und attackiert, von den Stoikern konsequent verteidigt wurde. Der bedeutendste römische Stoiker, Seneca, hat seine Auffassung vom fatum indes nirgends systematisch dargelegt. Der Beitrag stellt eine Auswahl der markantesten Äußerungen über das fatum aus den verschiedenen Werkgruppen zusammen (Naturales Quaestiones, De providentia, De vita beata, Consolatio ad Helviam, Epistuale morales, Epigramme, Tragödien) und ordnet sie interpretierend in den jeweiligen Kontext ein. Es zeigt sich, daß hinter den punktuellen Äußerungen eine in sich widerspruchsfreie und mit dem mainstream der Stoa übereinstimmende Lehre vom Schicksal zu rekonstruieren ist. Seneca problematisiert diese allerdings nirgends, sondern präsentiert sie seinen Lesern fast überall als selbstverständlich gültige Argumentationsbasis. Sein Interesse gilt den psychologischen Problemen der praktischen Akzeptanz des fatum, dem konkreten Umgang mit dessen scheinbarer Undurchschaubarkeit und Willkür. 
Roman philosophical writers, Cicero and Seneca, there is not one single title repeated. ${ }^{2}$ Apparently, in a conscious act of denied aemulatio, Seneca strictly avoided thematic doubles and, with it, direct comparison. Thus, Cicero's extensive discussion of metaphysics in his theological triad De natura deorum, De divinatione and De fato prompted Seneca to keep away from this field, to which he added only the small treatise De providentia, and to concentrate in his Naturales quaestiones on physics instead, which Cicero had not dealt with. Consequently, there is no Senecan epistemology and logic (fields to which the Stoics have actually got essential things to say) since the Stoic position had already been set out by Cicero in his Academica. While Cicero in the field of ethics discusses the officia, a topic close to the heart of any Stoic, Seneca presents the flipside of the do ut des in his De beneficiis. Cicero's political philosophy in De re publica and De legibus revolves around iustitia as its pivotal element; disregarding justice, Seneca focuses on clementia in his politico-philosophical treatise of the same name. While the genres of protreptic and systematic ethics are found only among Cicero's writings, with the Hortensius and De finibus bonorum et malorum, Seneca with his Epistulae morales ad Lucilium gives a practical introduction to philosophising in the form of philosophical letters, a genre that Cicero misses out. But the phenomenon is not restricted to the field of philosophy: it also includes the poetic output of both authors - hexametrical epic with De consulatu suo, didactic poetry with the Aratea and poems of Hellenistic stamp on Cicero's side, on Seneca's side tragedy, epigrams and satire. Among this strategy of avoidance may also be counted both the strange form of quasi-dialogue of Seneca's philosophical writings, which are neither true dialogue nor lecture, and his style of writing, which is distinctly new and different. Seneca's entire oeuvre may be seen as designed to complement Cicero's, which, as the basis for philosophical discussion, Seneca, as it seems, expects his readers to know. ${ }^{3}$ There are, of course, other important reasons for choice of titles and topics, genre and manner of presentation. All the same, Seneca did not write a systematic treatise De fato, while Cicero did, ${ }^{4}$ so that when looking for Seneca's notion of fate, there is nothing else to do but to collect the disiecta membra and hope for a plausible result of the reconstruction. ${ }^{5}$ Before presenting a selection of passages relevant to the question, let me briefly outline the biographic, literary and terminological background of the author.

my argument. I should also like to express my gratitude to Maxi Wandtner $(\dagger)$ for her perceptive comments in correspondence, and to Simone Thebrath, Michael Müller and Sebastian Rödder for critical readings of the manuscript. Many thanks are due to Elisabeth Begemann and Elisabeth Lösch for translating the original German version into English. Passages from Seneca are cited according to the translations of Basore, Corcoran, and Gummere in the Loeb series.

2 Whether Seneca's treatise on friendship, which is now lost except for a few fragments, and which is usually referred to in literature as De amicitia, actually carried this title and would thus have been a double to Cicero's Laelius de amicitia, cannot be decided; for the fragments, see HaAse, Senecae opera, vol. III, 435 f. (fr. 89-97).

3 On Seneca's judgement of Cicero, see Gambet 1970; Moreschini 1977, and Grimal 1984.

4 On Cicero's understanding of fate, see now the comprehensive study of BEGEMANN 2012.

5 This is also pointed out by ANDreoni Fontecedro 1992, 163, and BALdARotta 1994, 23, although both follow communis opinio in assuming a consistent system behind Seneca's various comments. 
The life of Seneca is so well-known and has been described so often that there is no need to dwell on it here. ${ }^{6}$ Considering his biography, an in-depth and personal approach to the concept of fate may be expected. To illustrate this, only a few points shall be mentioned. Born in Hispanic Cordoba into an equestrian family, Seneca belongs to the aspiring middle class of the provinces, who flood the capital, increasingly leave a distinct mark on its intellectual life and methodically plan their political career. After a short Pythagorean phase, Seneca becomes an adherent of the Stoa, the school of thought predominant among the Roman nobility - which certainly was no disadvantage for his progress in society. Rising, thanks to his outstanding rhetorical abilities, to become a prominent figure in the imperial power structure, he, like any other able senator, finds himself almost helplessly subject to the intrigues and squabbles of the court. Under Caligula, he only just manages to save his skin; by Claudius he is exiled to Corsica, whence he is recalled only eight years later on the request of the emperor's niece, and new wife, Agrippina. What follows is a late, but meteoric second rise, first as princely tutor, then - after the murder of Claudius - as Nero's adviser and super minister, determining for five years as joint ruler the policies of the Roman Empire. When the carefully balanced power structure of the imperial court collapses, Seneca's fall is sudden and deep. He resigns in $\mathrm{AD}$ 62, withdraws from public life, and is forced three years later, in the course of the Pisonic conspiracy, into suicide. Add to this roller-coaster of successes and failures in his political career his personal blows - the death of his first wife and of his children at a tender age, for example, and his repeated severe, even life-threatening, illnesses, such as an asthmatic condition - and you have every right to say that Seneca well knew the ups and downs of life in extenso, and that he had enough time to dwell on them whenever he was forced to political abstinence.

A good prerequisite for finding a detailed discussion of the issue of fate is the state of transmission of his oeuvre, which, although not in its entirety, has come down to us in substantial parts. ${ }^{7}$ However, we have not got any unpublished writings, private correspondence or diaries, but only texts filtered by literary conventions and political considerations and addressed at public audiences. Thus, Seneca's inmost thoughts are hardly ascertainable. Among his philosophical writings, the bulk of texts deals with ethical questions. Topics of individual ethics are treated in nine shorter dialogues and in the larger collection of the letters to Lucilius; questions of collective ethics are discussed in De beneficiis, questions of political philosophy in De clementia. Physics is the subject of the seven books of Naturales quaestiones. The small work De providentia is on the borderline between individual ethics and theology. The topical breadth of his oeuvre at least provided Seneca with the possibility of considering different aspects of the concept of fate, ontological reasons as well as ethical consequences. In addition to his philosophical writings, there is his poetry. Particularly while working on the tragedies, which stand

6 From amongst the abundant literature on his life, see especially the more recent monographs Grimal 1978; Griffin 1976; Rozelaar 1976; Sørensen 1984, and Funrmann 1997. For further literature up until 1989, see Motto, Clark 1989 and now the concise survey by HabineK 2014.

7 Good outlines of all writings, which also provide introductions to Senecan thought, are given in ABEL 1985, Maurach 2005, and by the contributions in Damschen, Heil 20 I4, I I 5-2 I 2, 425-5 II, and 673-695. Veyne 1993, and Inwood 2005 give introductory overviews of Seneca specifically as Stoic thinker. Various aspects of his thought are discussed in Damschen, Heil 2014, 217 -40I. 
in the tradition of Sophocles and Euripides, Seneca must have been confronted with the question of fate. Thus, it seems, the stage is set for a personal and in-depth reflection of heimarmene or fatum, a topic which per se figures prominently in the Stoa, the philosophy of his choice.

III.

The term 'fate' seems to have had its days in modern philosophy: "Seit der frühen Neuzeit zunehmend durch 'Notwendigkeit' und 'Determination' verdrängt, verliert der Schicksalsbegriff vom 19. Jahrhundert an seine fest umrissene Bedeutung. Sein konturloser und inflationärer Gebrauch in Weltanschauungen des 20. Jahrhunderts hat ihn

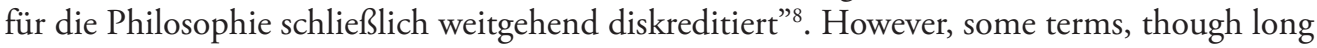
declared dead, find their happy resurrection; 'soul' is a case in point. At any rate, the issues connected with the word 'fate' - is human life determined by a higher power? how does divine providence relate to such a power? how much room is there left for freedom? what impact does it have on people's responsibility for their actions? - are invariably virulent even in everyday life, e. g. when German criminal law operates on the basic assumption that there is no determinism by fate or like powers because this would preclude accountability for actions and possibility of punishment.

In ancient texts, Babylonian and Egyptian, Greek and Roman, the term 'fate' is used to denote the broad phenomenon that there is, apart from the realm and power of the gods, another, essentially impersonal power that influences people's lives. How this impersonal power relates to the gods, whether fate is superior or subordinate to the gods, whether it interacts with them, whether the gods can change fate or prevent it - these questions have found different answers at different times. There is a third element added to fate and the gods: man, who in all ancient cultures attempts to learn, through divination, both the will of the gods and the future, as determined by fate, and to influence the course of events, whether determined by the will of the gods or by fate, by means of sacrifices, prayers, rituals. In the practical religiosity of all times the prevailing belief seems to be that people are not helplessly subject to fate, but that there is room to manoeuvre - to slow up fate, elude or overcome it, either by themselves or with the help of the gods.

The sphere of this essentially impersonal power is referred to already in the very first texts

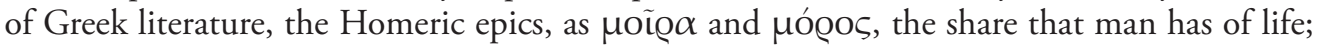
as $\kappa \eta ́ \varrho$, the appointed lot; in post-homeric Greek literature increasingly as $\tau \hat{\chi} \chi \eta$, which can mean not only chance, but also blind fortune, which is oblivious to bad or good; as $\alpha \tilde{\tau} \sigma \alpha$, the fate decreed by the gods; as $\alpha \dot{\alpha} \alpha \gamma \kappa \eta$, the force of circumstances; finally, in philosophy,

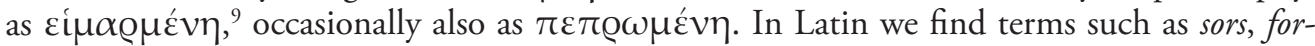
tuna, fatum, fata, as well as the Parcae as personification of an otherwise impersonal fate. All these terms are vague in that they are employed in philosophy, theology and poetry to denote slightly different things each, thus mirroring unfocussed everyday usage. ${ }^{10}$

8 Kranz 1992, 1275. For a concise overview of the conceptions of fate in ancient philosophies, cf. Kranz 1992, 1275-1280 (with literature). For a more detailed discussion, which includes religious conceptions of fate, see SCHRÖDER 1969, on Seneca in particular 542.

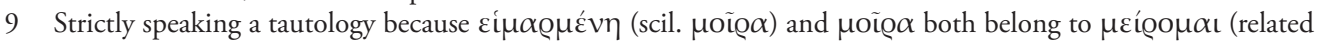
to the Latin stem mereo), "to have part in"; cf. LS, s.v. $\mu \varepsilon$ í $\mu \alpha$ ı (A) and TLL VIII s.v. mereo 802.

10 On the meaning of fatum and related terms, cf. the overview in ScHRöDER 1969, 525-529; on their evolution 
I $\mathrm{n}$ order to systematically determine Seneca's idea of fate, all possible terms denoting fate would need to be examined, and all references to fate in narratives, especially the exempla, as well as allusions and metaphors would have to be taken into account - a task as appealing as it is formidable. ${ }^{11}$ The following remarks will confine themselves to one single term, fatum, and to only a few instances in the Senecan oeuvre where it is used. While sors plays a minor role in Seneca, ${ }^{12}$ the term fatum occurs frequently in the philosophical writings and the tragedies, and considerably more often still does the term fortuna. ${ }^{13}$ Looking through the relevant passages, it seems as if Seneca regularly uses fatum for a fixed order of events, for the impersonal power as an objective entity, while fortuna is employed, taking the subjective human viewpoint, to denote the seemingly blind and unjust rule of fortune, i. e. so to speak the outside of fatum, referring to supposed adversities, whose inner logic and sense cannot (yet) be recognised, and which people are at first confronted with like with a blind force. ${ }^{14}$ Since in most of his writings it is Seneca's concern to provide aid and orientation for life and soul, it is not surprising that people's conflict with fate presenting itself as fortuna is given more scope than fatum as an objective fact. Yet, at the same time, there is no contradiction between the concept of fortuna as determined by the outside perspective, and the concept of a meaningful, even good, benign fate - fatum as determined by the inside perspective.

Looking at the concordances for the term fatum, we find 93 cases where the term is used in the singular, 28 of which occur in the tragedies. The plural fata is used 103 times, 65 times in the tragedies. This suggests that the singular is more "philosophical" than the plural. Despite the rather large numbers, the frequency of the technical term fatum, compared with the total size of the works, is not particularly high, a circumstance which can be seen clearly from the fact that, out of the 65 philosophic uses, almost one third (19) appear in a single short passage in the Naturales quaestiones (II 32-38). Fatum does not seem to play much of a role in Seneca's thought, or rather: fatum does not seem to be a term that Seneca struggles with, or which is of such central importance to his philosophical concerns as are fortuna or libertas.

It is also striking that the only passage that deals with the term fatum somewhat systemati-

in antiquity, cf. SCHröder 1969, 529-531. The etymology of fatum is analysed by PöTsCHER 1974, and, with repetitions, PöTsCher 1978, who advocates the hypothesis that fatum is not only a poetic, but an originally religious term. Almost exclusively concerned with the poetic usage of the term is the study of NeRI 1986, who 2046-2051 at least offers a sort of appendix on Seneca. The essentially artificial philosophical term heimarmene and its development from old Stoic determinism to astral fatalism is discussed briefly in GuNDEL 1912, and in detail in Gundel 1914; for the discussion in Christianity of the term heimarmene thus altered, see STEGEMANN 1939. Abundant material on heimarmene and tyche is provided by ANWANDER 1948.

11 Мотто 1970, s.v. Chance and s.v. God, conveys a sense of the wealth of material. Good observations on terminology, including some Senecan neologisms, are also to be found in ANDREONi FonTECEDro 1992, especially 165-170.

12 According to the concordances, Seneca uses sors in the philosophical writings about 45 times, in the tragedies about 33 times. See the frequency lists in Busa, Zampolli 1975, vol. 2; Denooz 1980, index; Delatte, EvRARD, Govaerts, Denooz 1981, index, vol. 2 (excluding nat. quaest.).

13 Delatte, Evrard, Govaerts, Denooz 1981, index, vol. 2, notes 409 occurences of the term fortuna in the philosophical works. In the tragedies it occurs, both as term and as personalised name, altogether 64 times, according to DenOoz 1980, index fortuna.

14 Hachmann 2000, 296, comes to an analogous result, with evidence provided from the Epistulae morales Hachmann 2000, 296-303. On the term fortuna, which is employed by Seneca both to denote an (apparently) hostile and inscrutable force and essentially as an equivalent of fatum, see BALDAROTTA 1994, $24 f$. 
cally and not just en passant is found in the Naturales quaestiones, a treatise not on ethics, but on physics. The other work of Seneca's undoubtedly important for establishing his notion of fate, De providentia, is, strictly speaking, not an ethical treatise either. To put the following observations on a somewhat broader basis, I shall also look at the Consolatio ad Helviam matrem, in which there is comparatively much argumentation with fatum, at De vita beata, which proves unable to exclude the issue of fate in its discussion of good luck and bad luck, at an epigram from the period of exile, and at passages from the Epistulae morales that highlight the problem and its pragmatic significance in compact form. Finally, looking at the Hercules furens, I shall try to determine the relationship of the tragedies to the philosophical discourse. First, however, leaving aside the historical development of Stoicism, the various contributions of its adherents, their differences as well as the subtleties of the school's teachings, I shall give a brief outline of the general Stoic system, enough to prepare for placing Seneca, who called himself a Stoic and was regarded as such, in the history and context of the school.

\section{V.}

The Stoics conceive of everything as material, non-transcendental. Partaking in a constant cyclic process, the world progresses in a teleological development from the creation of the cosmos by differentiation to the dissolution of the cosmos in the great conflagration, new creation, new conflagration, etc. Two elements, which in the beginning are present in their purest form and which will be restored to their purest form in the ekpyrosis, are involved in this process: passive matter, $\check{\lambda} \lambda \eta$, and active logos, also known as cosmic law or world soul or god. The supremely rational and good logos ensures the creation of the best of all possible worlds. This works because right from the beginning the world follows a stringent causality, with each determined state leading inevitably to the next, etc. until everything is consumed by fire in the ekpyrosis - all according to the perfect plan of the logos. Everything that happens is good, nothing happens by chance. Nobody interferes with the causal chain, not even god. So what we have here is a strictly deterministic system, with every single human life being determined, to failure as well as to success. The cosmic planning activity of the logos is also called fate (fatum/

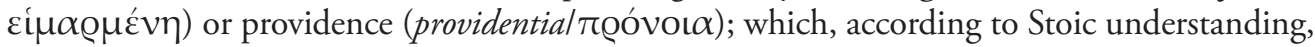
coincide. ${ }^{15}$ Benign providence, which wants the best and achieves the best, is directed - this seems to me to be the crucial point - not towards the individual person, but towards the cosmos as a whole. Understanding providence in this way considerably eases the tensions caused by the problem of theodicy, which Stoics, too, face, when they need to explain how the misfortunes of some people can be reconciled with divine benevolence and justice.

15 For conceptions of fate in ancient philosophy, see the seminal book of MAGRIs 1984-85, who provides a detailed documentation of the controversy about Stoic determinism vol. 2, 479-607. Among the older works on the Stoic conception of fate, cf. Arnim 1905; Amand de Mendieta 1945; Valgiglio 1967/68; Reesor 1978; Stough 1978. Wildberger 2006, 276-351, develops the Stoic system according to Seneca's writings and in the light of the latest research on the topic. In addition, PoHLEnz 1984/90, is also still of value. An overview of Seneca's notion of fatum is also given by ANDrEoni FonTECEDro 1992, who 161-163 calls attention to Seneca's orthodox view that fate and Stoic god are understood to be the same, which follows Chrysippus and Zeno, not Cleanthes. For an outline of the general Stoic position, see Brennan 2005, 235-241, who rightly points out that the text is not driven by primarily ethic considerations. 
By the rational part of their souls humans share in the world soul. Since it is this what makes up his differentia specifica from other animals, the Stoic secundum naturam vivere, 'to live according to nature', with regard to humans means to live rationally. The Stoa is radically intellectualistic.

From the point of view of individual human beings, their actions, in fact the whole of their existence are governed from the very first beginning by an unchangeable, causally determined fate, about which nothing can be done, neither by themselves nor any god. The best possible plan for the cosmos devised, the Stoic god has parted with all initiative and, since he abides by his plan, is henceforth powerless, much like Aristotle's 'unmoved mover'. It is up to the individual, who seems to be helplessly subject to fate, to recognise what good there is in his own personal fate. Such recognition results in true happiness: unusquisque facere se beatum potest (Helv. 5,1), an enormous ability and immense power. Stoicism has an incredibly high opinion of people, or rather: some people and their intellectual abilities - which is clearly coupled with the distinct danger of expecting too much from them, and which may well be the reason for speaking so frequently of suicide as the easy way out.

$V I$.

few years before he was himself forced to part with life this way, Seneca wrote the Natu-
rales quaestiones, for which he had collected a lot of material over many years. In spite of
some recent monographs, they still belong to the less well-known part of his oeuvre. ${ }^{16}$ They are scientific studies with a true interest in the phenomena discussed, yet philosophically imbued throughout, the guiding question being whether and how rational and, in particular, causal explanations can be found for these natural phenomena, and whether these point to a rational order behind them. The consideration of scientific questions has a long-standing tradition in Stoicism. For, since the Stoics assume a rational cosmic order, they early on found themselves involved in proving how this order applies to the world; examples repeatedly cited to prove the existence of the Stoic god, of well-ordered nature, of providence include the regular movement of the fixed stars and the functional creation of human beings with all their limbs and organs. ${ }^{17}$

Seneca places his studies thematically between the realms of fixed stars and of animate beings by discussing phenomena such as rainbows, polar lights, lightning and thunder, the water cycle, snow and hail, the winds, earthquakes, and many more. The composition of the seven books follows a fairly systematic, descending order, from phenomena in the sublunary sphere to the origins of earthquakes in the depth of the earth. The second book, to which the passage on fate presented in the following belongs, specifically deals with lightning. ${ }^{18}$

16 For a good overview of all central introductory questions of the Naturales quaestiones, see SCHÖNBERGER, SCHÖNBERGER 1990, 13-45, with 28-32 for a breakdown of the contents and 40-45 for a selected bibliography until 1989. Hine 1980, and HiNe 1996b, provide a new foundation for textual criticism; cf. also his commentary on book 2, which is very rich in material (HINE 1981). On sources, composition and intended message, see the fundamental studies of WAIBLINGER 1977; Gross 1989; Gauly 2004, and the recent account of WiLliams 2014.

17 See the overview in PoHLEnz 1984/90, vol. 1, 98-101.

18 On how to place this book within the discourse of the early imperial age, which saw a growing separation of religion and science, see Williams 2012, 295-297, on the structure of the book, the centre of which is the passage II 32-51, see Williams 2012, 298. 
This topic unquestionably holds great attraction for the Stoic because it is difficult to find any rational explanation for the occurrence of lightning, because the apparently arbitrary phenomenon of lightning strikes raises the issue of contingency, and because lightning was traditionally seen as a spontaneous expression of divine will and thus played an important role as prodigy in Roman divination. Like other prodigia, lightning strikes (especially when hitting a temple or other public buildings) were subject to fixed procedures of interpretation, which consisted of reporting the incident to the senate, confirming it as prodigium, consulting, if necessary, the appropriate college of priests, and deciding on measures of expiation to avert, defer, or reduce disaster, philosophically speaking: to influence the gods or fate - a ridiculous idea in the eyes of any Stoic. This is probably the reason why the treatment of lightning strikes is given so much room in the second book. And Seneca used this convenient topic to systematically discuss fatum. Jula Wildberger, Susanna Fischer and Gareth D. Williams have recently presented comprehensive and richly documented discussions of the passage (nat. quaest. II 32-38), on which the following remarks draw. ${ }^{19}$ As Seneca develops his position in dialogue form, by means of a staged dispute between Stoics and their critics - whose arguments, coming from different sources, are hardly intended to form a consistent system, but rather to reflect a hotchpotch of anti-Stoic reservations -, speaker changes need to be considered carefully.

The discussion nat. quaest. II 32.1 takes as its starting point the belief that lightning has the property of being capable to indicate the future, which is vehemently advocated by the Stoic because he sees it as an argument for the non-contingent occurrence of this phenomenon: "What about the fact that lightning foretells future events and gives signs not only of one or two events but often announces a long series of successive fates, actually with far more obvious and clearer marks of evidence than if these were in writing." 20 This fact, on which Stoics generally agree with adherents of traditional Roman religion and especially of divination, is, however, not explained with gods sending signs (a traditionalists' objection, which is immediately taken up by the critic) - for lightning, in Stoic opinion, has purely natural causes -, but by arguing that within a strictly deterministic system everything points to what is to come by being part of the causal chain. Divination is possible because in a cohesive system an event or situation $b$ can be conclusively predicted on the basis of an event or situation $a$. Therefore lightning-flashes are only like some sort of window that makes it particularly easy for people to see the causal chain and, with it, the future:

This is the difference between us and the Etruscans, who have consummate skill in interpreting lightning: we think that because clouds collide lightning is emitted; they believe that clouds collide in order that lightning may be emitted. Since they attribute everything to divine agency they are of the opinion that things do not reveal the future because they have occurred, but that they occur because they are meant to reveal the future. Whether it is displaying their purpose or their consequences they none the less occur on the same principle. "But how do things indicate future events unless they are sent to do so? In the same way as birds provide favourable or unfavourable auspices even

19 See Wildberger 2006, 321-346; Fischer 2008, 185-197, and Williams 2012, 319-324, who 314-319 analyses the differences between Seneca and Cicero with regard to this problem. In addition, see also Setaioli 2014 passim.

20 Nat. quaest. II 32.1 quid quod futura portendunt, nec unius tantum aut alterius rei signa dant, sed saepe longum fatorum sequentium ordinem nuntiant, et quidem notis euidentibus, longeque clarioribus quam si scriberentur? The Latin text is that of HiNe 1996a. 
though they are not, in this respect, moved in order to appear to us. "But god moved them", he says. Make god too unoccupied and the administrator of trivia if he arranges omens for some people, entrails for others.

None the less, such things are carried out by divine agency, even if the wings of birds are not actually guided by god, nor the viscera of cattle shaped under the very axe. The roll of fate is unfolded on a different principle, sending ahead everywhere indications of what is to come, some familiar to us, others unknown. Whatever happens, it is a sign of something that will happen. Chance and random occurrences, and without a principle do not permit divination. Whatever has a series of occurrences is also predictable. ${ }^{21}$

How exactly he conceived of this window onto the future, the indicia familiaria, Seneca did not elaborate. Maybe he thought that the causal nexus of lightning and future event, which is usually hidden to everyone but the extra-temporal Stoic god, is more clearly evident here so that more reliable conclusions can be drawn about the future. In particular, when compared to bird flight or the constellation of stars, which, too, permit conclusions about the fatum (nat. quaest. II 32.5-7), it shows that according to Stoic understanding all these phenomena indicate the future only because they are part of the causal chain, as Seneca emphatically underlines, using the phenomenon of lightning as an example to set off the Stoic position against that of the disciplina Tusca:

"People conclude that the power of lightning is supreme because the intervention of lightning annuls whatever other omens portend; whatever is foretold by lightning is unalterable und unchanged by the indication of another sign. [...] On this point they seem to me to be mistaken. Why? Because nothing is truer than the truth. If birds have foretold the future such an auspice cannot be nullified by lightning - or they foretold what was not the future. I am not now comparing a bird with lightning but two revelations of the truth which, if they do foretell the truth, are the same. So, if the intervention of lightning negates the revelations of the entrails or of augury the entrails have been improperly examined, the augury improperly observed. For it does not matter whether the appearance of one or the other omen is larger or more powerful by nature; if both have given indications of the truth they are equal as far as it pertains to the truth. [...] Because it makes no difference how many omens there might be. Fate is single. If fate is correctly understood from the first omen it does not become destroyed by the second omen. So I say it does not matter whether we seek the truth by one means or another since the truth which is sought is the same. Fate cannot be altered by a lightning stroke. Why not? For lightning itself is part of fate." 22

21 Nat. quaest. II 32.2-4: Hoc inter nos et Tuscos, quibus summa est fulgurum persequendorum scientia, interest: nos putamus quia nubes conlisae sunt fulmina emitti; ipsi existimant nubes conlidi ut fulmina emittantur. nam cum omnia ad deum referant (Corcoran erroneously: referent), in ea opinione sunt tamquam non quia facta sunt significent, sed quia significatura sunt fiant. eadem tamen ratione fiunt siue illis significare propositum siue consequens est. 'quomodo ergo significant, nisi ideo mittuntur?' quomodo aues, non in hoc motae ut nobis occurrerent, dextrum auspicium sinistrumque fecerunt. 'et illas' inquit 'deus mouit'. nimis illum otiosum et pusillae rei ministrum facis, si aliis omina (Corcoran: somnia who translates: "dreams"), aliis exta disponit. ista nibilominus diuina ope geruntur si non a deo pennae auium reguntur, nec pecudum uiscera sub ipsa securi formantur. alia ratione fatorum series explicatur, indicia uenturi ubique praemittens, ex quibus quaedam nobis familiaria, quaedam ignota sunt. quidquid fit, alicuius futurae rei (Corcoran: rei futurae) signum est. fortuita et sine ratione uaga diuinationem non recipiunt; cuius rei ordo est, etiam praedictio est.

22 Nat. quaest. II 34.1-35,1: Summam esse vim fulminis iudicant, quia, quidquid alia portendunt, interuentus fulminis tollit; quidquid ab hoc portenditur fixum est, nec alterius ostenti significatione mutatur. (...) in quo mihi falli uidentur. 
The question what the point is of the traditional means of expiation and purification is answered by Seneca dialectically, maybe because it was a disputed question within the Stoa itself, or because he wanted to uphold both positions of his school against its critics. In a first line of argument nat. quaest. II 35-36, he presents himself as a strict determinist. Any influencing of fate as indicated by lightning strikes is impossible. Rituals intended to change fate are therefore meaningless and at best useful in the sense of a theologia popularis as a means to comfort the uneducated masses:

"Well, then, what use are expiations and precautions if the fates are immutable?" Permit me to support that rigid sect of philosophers who reject such practices and consider them only a solace for a troubled mind. The fates perform their function otherwise and are not moved by any prayer. The fates do not know how to be turned by pity or by favour. Once started upon an irrevocable course they flow on in accordance with an unalterable plan. Just as the water of a rushing torrent does not flow back upon itself and does not even pause since the flood coming from behind pushes ahead the water that passed before, so the eternal sequence of events causes the order of fate to roll on. And this is its first law: to stand by its decrees. What do you understand as fate? I consider it the necessity of all events and actions which no force may break. If you think this is averted by sacrifices or by the head of a snow-white lamb, you do not understand the divine. It is your saying that the decision of a wise man cannot be changed. How much more true this is in the case of a god! A wise man knows what is best in the present. For god's divinity everything is the present. ${ }^{23}$

quare? quia uero uerius nibil est. si aues futura cecinerunt, non potest hoc auspicium fulmine inritum fieri; aut non futura cecinerunt. non enim nunc auem comparo et fulmen, sed duo ueri signa, quae, si uerum significant, paria sunt. itaque <si> (Corcoran omits si) quae fulminis interuentus submouet extorum uel augurii indicia, male inspecta exta, male seruata auguria sunt. non enim refert utrius rei species maior sit uel natura potentior; si utraque res ueri attulit signa, quantum ad hoc par est. (...) quia nihil interest quam multa auspicia sint: fatum unum est; quod si bene primo auspicio intellectum est, secundo non interit. ita dico: non refert an aliud sit per quod quid[em] (Corcoran: quidem) quaerimus, quoniam de quo quaeritur idem est. fatum fulmine mutari non potest. quidni? nam fulmen ipsum fati pars est.

23 Nat. quaest. II 35.1-36.1: 'Quid ergo? expiationes procurationesque quo pertinent, si inmutabilia sunt fata?' permitte mihi illam rigidam sectam tueri eorum qui fexcipiunt † (Corcoran: risu excipiunt who translates "accept ... with a smile") ista, et nibil esse aliud quam aegrae mentis solacia existimant. fata aliter ius suum peragunt, nec ulla commouentur prece; non misericordia flecti, non gratia sciunt; cursum inreuocabilem ingressa ex destinato fluunt. quemadmodum rapidorum aqua torrentium in se non recurrit, ne moratur quidem, quia priorem superueniens praecipitat, sic ordinem fati rerum aeterna series rotat, cuius haec prima lex est, stare decreto. Quid enim intellegis fatum? existimo necessitatem rerum omnium actionumque quam nulla uis rumpat. hanc si sacrificiis aut capite niueae agnae exorari iudicas, diuina non nosti. sapientis quoque uiri sententiam negatis posse mutari; quanto magis dei, cum sapiens quid sit optimum in praesentia sciat, illius diuinitati omne praesens sit! The obviously corrupt excipiunt in II 35.1 which is found in all MSS and which Hine puts between cruces desperationis, demands emendation by a verb that expresses the rejection of expiationes and procurationes, which most suggestions do, such as Fromondus' exsibilant, Madvig's despiciunt, or Oltramare's <risu> excipiunt; following Brakman, excutiunt has been chosen here for the translation, which is paleographically a comparatively minor correction; this is a word Seneca is fond of (there are around 90 occurrences in the philosophical treatises), probably because of its expressiveness; it is often used metaphorically to denote categorical rejection (cf. the references in TLL V II s.v. excutio I A 1 b translate i.q. repudiare, non respicere ... i.q. reicere, damnare). A different course is adopted by Rossbach, who, thinking that Seneca picks up on the term expiationes procurationesque, reads expiamenta ista instead of excipiunt ista et (with problematic atethesis of et). On this and further problems of textual criticism in the passage, see STOK 1995, who with Parroni plausibly argues for emending fata aliter ius suum peragunt, nec ulla commouentur prece; non misericordia flecti, non gratia sciunt to fata aliter iussum peragunt, etc., given the imitation of Virgil 
Thus it seems as if things were heading for a rejection of the traditional religion, but Seneca adds another line of argument nat. quaest. II 37-38, which again starts from a deterministic position, yet proceeds more subtly to save traditional cult practice after all, as becomes a good Roman and a civic philosophy. The principle that influencing fatum is impossible is not given up - "we also believe vows are useful if they do not impair the force and power of fate" 24 -, but the intellectual superstructure of traditional divination practices is so to speak exchanged to give new reasons for their meaningfulness.

It is reasonable after all to perform the practices to expiate, alleviate, and defer evil prodigies, since prayers, as the surprised reader now learns, do have an effect on the course of events: "For, some things have been left so in suspense by the immortal gods that they turn to our advantage if prayers are directed to the gods, if vows are undertaken." 25 The phrasing of this new circumstance, which seems to contradict what has been argued so far, must arouse the suspicion that the author relinquished the postulate of a strict determinism. But I agree with Wildberger in thinking that this is in fact not the case, but rather that the provocative phrasing is intended to motivate the ensuing discussion of anti-deterministic arguments. For the critic now turns to an argument that we, with Cicero's De fato in mind, might well have expected

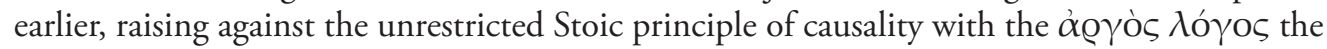
classic objection, which is based on the premise of strict determinism: "Either it is to be or is not to be. If it is to be it will happen even though you make no vows. If it is not to be it will not happen even though you do make vows." ${ }^{26}$ No matter whether somebody performs rites of expiation or not: if there is strict determinism, fate must turn out the same. This leads not only to the conclusion that all measures of expiation are useless, but also - since any action could be substituted - that all human activity itself is pointless and superfluous. But since the pointlessness of human action is an unacceptable consequence, it is the premise - total determinism that must be wrong; this is what the Lazy Argument implies. It is significant that Seneca needs to cite only the first clause of the argument for his readers to understand, they being well-versed in Ciceronian philosophy, and that the ensuing discussion can be kept very brief.

Seneca's reply is similar to Chrysippus' in Cicero, by introducing secondary causes, the confatalia, though the terminus technicus is lacking: "Such a dilemma is not valid because you omit an alternative between the two: this is to be, but only if vows are made." 27 In response, the interlocutor insists that the introduction of secondary causes, which of course are themselves determined, too, does not at all change the premise of strict determinism: "This also", he says, "needs to be included in fate: either that you make vows or you do not." ${ }^{28}$ Seneca concedes this point, but he also shows with the help of examples that the introduction of secondary causes at least frees man to become active again: "It is fate that so-and-so will become eloquent but only

(Aen. 6.376: desine fata deum flecti sperare precando together with the further context) at the beginning of the sentence, and who with some reservation goes even further in proposing iter instead of aliter.

24 Nat. quaest. II 37.2: nos quoque existimamus uota proficere salua ui ac potestate fatorum.

25 Nat. quaest. II 37.2: quaedam enim a dis inmortalibus ita suspensa relicta sunt ut in bonum uertant si admotae dis preces fuerint, si uota suscepta.

26 Nat. quaest. II 37.3: 'Aut futurum' inquit 'est aut non. si futurum est, fiet, etiamsi vota non suscipis. si non est futurum, etiamsi susceperis vota, non fiet.'

27 Nat. quaest. II 37.3: falsa est ista interrogatio, quia illam mediam inter ista exceptionem praeteris: futurum est hoc (Corcoran: hoc est), sed si vota suscepta fuerint.

28 Nat. quaest. II 38.1: 'Hoc quoque' inquit 'ipsum necesse est fato comprensum sit, ut aut suscipias vota aut non.' 
if he has learned literature. But by the same fate it is required that he learn. So, he must become learned." ${ }^{29}$ In this way, I think, Seneca really refutes one aspect of the Lazy Argument, i. e. the literal reading that humans will be robbed of all drive to act if everything just does come as it must. For the mere practice of the disciplina Tusca sufficient reason has thus been found. All other questions ensuing from this argument - what part humans have in their actions, how freedom and responsibility relate to fate - are not yet answered, however. Seneca recognises and names these issues before he concludes his theoretic discussion of fatum:

Such reasoning is usually presented to us in order to prove that nothing is left to our free will and that all control of action is handed over to fate. When this matter will be discussed I will tell how something may exist in man's choice while fate remains undiminished. But for the moment, regarding the point being treated, I have explained how, even if the order of fate is unalterable, expiations and preventations may avert the dangers of omens because they are not in conflict with fate but also themselves exist in the law of fate. "Well, then," you say, "what benefit is a soothsayer to me? In any case it is necessary for me to offer expiation even though he does not advise me to." He provides this benefit: the fact that he is a minister of fate. Thus, although the recovery of good health is owed to fate it is also owed to the doctor because the benefit of fate came to us through his hands. ${ }^{30}$

Seneca did not deliver on his promise to discuss the problem of freedom of action, at least not in the extant works; maybe more was said on the subject in the moralis philosophia. Since it is tempting to continue the train of thought at this point, I shall at least briefly sketch how Seneca, as his writings suggest, may have conceived of the problem of freedom. Seneca would probably have declared the question of choice between two options to be irrelevant. When he speaks of freedom, he mostly means freeing oneself from what restricts the rational mind and, in its course, the will, i. e. freedom from passions. To be unfree, essentially means that mental activity is restricted if and whenever the mind succumbs to the passions so that rational conclusions cannot be reached anymore: someone who is angry does not consider what he had best do, but only wants to strike, even though the consequences may be disastrous. Any judgement is sound only if it recognises what is best without external interference. What is best, however, is, according to Stoic understanding, what everyone is destined for by benign providence, logos, god, nature, fate, according to its perfect cosmic plan. Therefore, the sage cannot want anything else for himself but what fate, in the interests of the cosmic plan, has decided for him, and it is in this ready submission to fate that true freedom lies. The contrast between what fate forces on humans and what humans consider to be supposedly better, is only a contrast in seeming, not a real one. The feeling of being helplessly subject to fate is a mere lack of understanding of the greater mechanisms that are at work in the universe: it is man's fault, not fate's. ${ }^{31}$

29 Nat. quaest. II 38.2: fatum est ut hic disertus sit, sed si litteras didicerit; at eodem fato continetur ut litteras discat: ideo docendus est.

30 Nat. quaest. II 38.3-4: ista nobis opponi solent, ut probetur nibil uoluntati nostrae relictum, et omne ius faciendi $<$ fato $>$ traditum. cum de ista re agetur, dicam quemadmodum manente fato aliquid sit in hominis arbitrio; nunc uero id de quo agitur explicui, quomodo, si fati certus est ordo, expiationes procurationesque prodigiorum pericula auertant: quia non cum fato pugnant, sed et ipsae in lege fati sunt. 'quid ergo' inquis 'aruspex mihi prodest? utique enim expiare mibi etiam non suadente illo necesse est.' hoc prodest, quod fati minister est; sic cum sanitas debeatur fato, debetur et medico, quia ad nos beneficium fati per huius manus uenit.

31 On Seneca's remarks on the problem of free will, see BALdARotTa 1994; ZöLler 2003, 219-233; INWOOD 
It is remarkable how lightly the discussion of fatum is presented in the Naturales quaestiones. The task of defending the Stoic doctrine is undertaken almost playfully, with a kind of ironic, distanced politeness (permitte mibi illam rigidam sectam tueri II 35.1), as if the speaker spontaneously decided on it (agere nunc causam eorum volo qui procuranda existimant fulmina II 37.1), while the exuberant phrasing, e. g. of concessions (puta me tibi manus dare et fateri hoc quoque fato esse comprensum II 38.1), demonstrates his superiority. There is no element of doubt in Seneca, he rather conveys the impression to the reader of proceeding from a firm philosophical foundation.

CC Tou have asked me, Lucilius, why, if a Providence rules the world, it still happens that many evils befall good men."32 This question of his young friend Lucilius heads the
treatise De providentia, which was written around the same time as the Naturales quaestiones. ${ }^{33}$ The question can mean different things in different contexts: it can be criticism of god, of the concept of providence, of the object of the rigid Stoic moral standards, which does not seem to yield any discernible reward. As Lucilius has already become an adherent of Stoicism, the question is probably meant to express his uneasiness about a phenomenon that has not yet been explained to satisfaction. In contrast with the Naturales quaestiones, the discussion is marked by a fatherly understanding of the reservations of the addressee, who after all does not engage in any fundamental criticism of Stoic philosophy. Consequently, Seneca expressly does not defend the concept of providence as such, ${ }^{34}$ but rather seeks for explana-

2008, and Setaioli 20I4 (on the Lazy Argument ibid. 289-293). For the larger context, Dihle 1982 is still indispensable; on Stoicism, generally, see Bobzien 1998 (on the Lazy Argument ibd. 180-233) and Maso 2014. An excellent introduction to Stoicism with the focus on its peculiar understanding of will, freedom and soul are the lectures of FREDE 2011, who finds the concept of free will present in Seneca not yet, but first in Epictetus, and traces its development in later Stoicism, Platonism, and Christianity. Frede ignores Scotr 1986, who very knowledgably discusses the attractive thesis that Seneca attempts to make the freedom of human will thinkable within the traditional Stoic determinism (on the orthodoxy of Seneca's notion of fatum, see 15-35) by developing an unorthodox, dualistic, and slightly Platonic doctrine of soul in assuming that the act of will is either rational or - from first impulse - entirely irrational, and thus without any share in logos and fatum (73-105, a summary of the thesis 106-115). However, the latest contribution to Seneca's theory of action by Maso 2013 argues that Seneca anticipates Epictetus' notion of freedom by introducing a concept which locates the very beginning of action in "volition" which is originally in our power. On the ancient discussion whether Stoicism does not actually remove from people accountability and thus responsibility for their actions, see BRENNAN 2005, 242-269 (on the Lazy Argument ibid. 270-287).

32 Prov. 1.1: Quaesisti a me, Lucili, quid ita, si providentia mundus ageretur (Basore: regeretur), multa bonis viris mala acciderent. The text of De providentia is REYNOLD's.

33 For a good overview of the treatise, see Abel 1967, 97-123 and, for a short outline, Scott Smith 2014; NiEm 2008, lists the most recent literature; for an introduction to Seneca's thoughts on providence in De providentia and elsewhere, see Fischer 2008, 11-56; on the conception of fatum in the central passage, prov. 5,7 f., cf. Andreoni Fontecedro 1992, 163-165. Like almost all of Seneca's writings De providentia is difficult to date. GiancotTi 1957, 244-309, who provides a useful synopsis of earlier suggestions in his appendix, considers it to belong either to the beginning of Seneca's exile or to the end of his life after his retirement; with the latter dating Abel 1985, 704, concurs in his overview on the chronology of Seneca's works. On the difficulties of dating Seneca's works in general and especially De providentia, see Marshall 2014, 37 and Scotт Smith 2014, $115 \mathrm{f}$.

34 Cf. prov. 1.2 . 
tions, as other Stoics had done before him, finding them on various levels: logos, in ordering the world, was bound to matter, hyle, and its restricted possibilities, which resulted in certain negative circumstances; nothing can exist without its opposite: therefore, since good exists, evil must also exist; the single parts of the perfect world need not themselves be perfect, too, etc. ${ }^{35}$ Seneca proceeds in two stages: First, he puts the idea of evils that befall the good in perspective: these, he says, are not real evils at all (mala), but, at the most, mere adversities (adversa) that do not reach their souls. Then he credits these adversities with fulfilling a useful function within the cosmic plan in having an educational effect. This last point, which is discussed in great detail and illustrated by many examples, dominates the treatise, which thus concentrates not on fate as an objective fact, but on the subjective problem of how to deal with it, promoting a positive understanding of supposed misfortunes. For the educational effect that the adversa have on those who have started on the path to wisdom is comparable to that of strict teachers, who toughen them up so that they may in time become true sapientes, godlike creatures - a goal well worth the effort:

I shall reconcile you with the gods, who are ever best to those who are best. For Nature never permits good to be injured by good; between good men and the gods there exists a friendship brought about by virtue. Friendship, do I say? Nay, rather there is a tie of relationship and a likeness, since, in truth, a good man differs from God in the element of time only; he is Gods' pupil, his imitator, and true offspring, whom his allglorious parent, being no mild taskmaster of virtues, rears, as strict fathers do, with much severity. And so, when you see that men who are good and acceptable to the gods labour and sweat and have a difficult road to climb, that the wicked, on the other hand, make merry and abound in pleasures, reflect that our children please us by their modesty, but slave-boys by their forwardness; that we hold in check the former by sterner discipline, while we encourage the latter to be bold. Be assured that the same is true of God. He does not make a spoiled pet of a good man; he tests him, hardens him, and fits him for his own service. ${ }^{36}$

The special treatment and the strict training in virtus the chosen good receive from supposed misfortunes are consistently interpreted by Seneca as privileges granted to this elite corps of the Stoic god:

Why is it that God afflicts the best men with ill health, or sorrow, or some other misfortune? For the same reason that in the army the bravest men are assigned to the hazardous tasks; it is the picked soldier that a general sends to surprise the enemy by a night attack, or to reconnoitre the road, or to dislodge a garrison. Not a man of these will say as he goes, "My commander has done me an ill turn," but instead, "He has paid me a compliment." In like manner, all those who are called to suffer what would make

35 For the different models of explanation, see Wildberger 2006, 276-283, and Fischer 2008, 21-29.

36 Prov. 1.5 f.: In gratiam te reducam cum dis aduersus optimos optimis. Neque enim rerum natura patitur ut umquam bona bonis noceant; inter bonos uiros ac deos amicitia est conciliante virtute. Amicitiam dico? immo etiam necessitudo et similitudo, quoniam quidem bonus tempore tantum a deo differt, discipulus eius aemulatorque et uera progenies, quam parens ille magnificus, uirtutum non lenis exactor, sicut seueri patres, durius educat. Itaque cum uideris bonos uiros acceptosque dis laborare sudare, per arduum escendere, malos autem lasciuire et uoluptatibus fluere, cogita filiorum nos modestia delectari, uernularum licentia, illos disciplina tristiori contineri, horum ali audaciam. Idem tibi de deo liqueat: bonum uirum in deliciis non habet, experitur indurat, sibi illum parat. 
cowards and poltroons weep may say, "God has deemed us worthy instruments of his purpose to discover how much human nature can endure." ${ }^{37}$

But the apparent misfortunes of the good, where they are borne with fortitude, have an educational effect also on the masses of the non-chosen, because only this way may they recognise that exile, pain and grief are in fact $\alpha \delta$ ś $\phi$ o@ $\alpha$ :

Consider, too, that it is for the common good to have the best men become soldiers, so to speak, and do service. It is God's purpose, and the wise man's as well, to show that those things which the ordinary man desires and those which he dreads are really neither goods nor evils. It will appear, however, that there are goods, if these are bestowed only on good men, and that there are evils, if there are inflicted only on the evil. Blindness will be a curse if no one loses his eyes but the man who deserves to have them torn out; therefore let an Appius and a Metellus be deprived of the light. ${ }^{38}$

It would be misunderstanding Seneca to see his advice to patiently bear misfortunes and to regard them as a school for virtue as a general rule of life. With Lucilius as the ideal reader the primary group of addressees is rather restricted to an elite minority of Stoics. Seneca basically says, Only you, who are strong and good, are expected to abide by this advice, since you alone are able to understand and follow it. However, anyone who endures their misfortunes with fortitude may then proudly count themselves among this elite and see in their adversities proof positive of their close proximity to god. Thus, the reinterpretation of adversa as exercises in virtue and exempla for the masses has not only got the objective effect of giving meaning to misfortunes as blessings of god, but also - which may be even more important - the psychological effect of making supposed misfortunes and the ability to embrace them a constitutive characteristic of the elite. Personal suffering is thus in a way compensated for by the feeling of elation $^{39}$ of belonging to a select group of privileged people and of having the honour of being named in one breath with heroes like Appius and Metellus. This pattern of argumentation can be regarded as a clever move to further enhance the attraction of Stoic philosophy particularly within Roman aristocratic circles, whose actual political importance had massively declined during the principate, and who were especially subject to the emperors' whims. For what could hold more attraction for them than a philosophy that seemed to be expressly developed for the strong and good, assigning to them as fields where to exercise virtus - once traditional Roman, now Stoic - the very misfortunes which they de facto had to face anyway: exile, pain, death, and grief, and offering them to draw renewed self-esteem from them of all things.

37 Prov. 4.8: Quare deus optimum quemque aut mala ualetudine aut luctu aut aliis incommodis adficit? quia in castris quoque periculosa fortissimis imperantur: dux lectissimos mittit qui nocturnis hostes adgrediantur insidiis aut explorent iter aut praesidium loco deiciant. Nemo eorum qui exeunt dicit 'male de me imperator meruit', sed 'bene iudicauit'. Idem (Basore Item) dicant quicumque iubentur pati timidis ignauisque flebilia: 'digni uisi sumus deo in quibus experiretur quantum humana natura posset pati.'

38 Prov. 5.1 f.: Adice nunc quod pro omnibus est optimum quemque, ut ita dicam, militare et edere operas. Hoc est propositum deo, quod sapienti uiro, ostendere haec quae uulgus adpetit, quae reformidat, nec bona esse nec mala; apparebit autem bona esse, si illa non nisi bonis uiris tribuerit, et mala esse, si tantum malis inrogauerit. Detestabilis erit caecitas, si nemo oculos perdiderit nisi cui eruendi sunt; itaque careant luce Appius et Metellus.

39 ANDREONI FonTECEDro 1992, 164, pointedly speaks of "mysticism of obedience". 
VIII.

$\mathrm{W}$ hile De providentia thus reads less as a theoretical treatise than as a didactic comment on the best way to deal with adversities, which claims to be of, while not universal, yet still superindividual validity, Seneca's writings that were composed approximately twenty years earlier during the period of his exile show his attempt to grapple with his own personal misfortune.

In the Anthologia Latina the following poem is transmitted under Seneca's name:

Devouring Time all things consumes and wastes;

By Time all things are changed, and nothing lasts.

Rivers will fail, and roll their streams no more;

And seas receding will leave dry the shore:

The mountain's mass, and alpine cliffs sublime,

Must sink recumbent with the weight of time.

But what are these? Yon beauteous dome the sky

Shall burst in flames from its own galaxy.

Death all things claims - Destruction is the doom

Of Nature, not a penance. Time shall come,

When this fair Universe at length destroyed

Will leave all space a nothing and a void. ${ }^{40}$

Although the authenticity of the poem cannot be proven with absolute certainty, the pointed imitation of Ovid ${ }^{41}$ fits the contemporary appreciation of the poet and the situation of this fellow exile. The content itself may be called good Stoic. Surprisingly, the poet draws comfort from the contemplation of nature - here: its transience (v 1-4) -, and from placing his considerations in the larger context of the cosmic cycle, which ends for the best of all worlds (moles pulcherrima, v 5) in the ekpyrosis (v 6), and which is summed up as the reign of death (omnia mors poscit, v 7). He recognises that death is not (individual) punishment, with which he could be threatened, or which he would have to fear, but a universal law to which the entire pres-

40 De qualitate temporis: Omnia tempus edax depascitur, omnia carpit, / omnia sede movet, nil sinit esse diu. / flumina deficiunt, profugum mare litora siccat, I subsidunt montes et inga celsa ruunt. I quid tam parva loquor? moles pulcherrima caeli / ardebit flammis tota repente suis. I omnia mors poscit; lex est, non poena, perire; / hic aliquo mundus tempore nullus erit (AL 224 (S.B.) (= 232 R.), cited according to SHACKLETON BAILEY 1982; the translation is that of John Dunlop (1838). Rich documentation of similia is already provided in Prato 1955, who gives evidence for the many correspondences of these eight verses with Seneca's philosophical works and his tragedies. For recent detailed commentaries, see Dingel 2007 (on our poem, see 99-102); Breitenbach 2010 (17-24), and Breitenbach 2009 (17-24). While Dingel advocates Senecan authorship (24), Breitenbach 2010, 1-15 convincingly dates the origins of the book of Senecan epigrams to the second century. However, this does not preclude, in my opinion, the possibility that single poems might be older and genuinely Senecan, being incorporated - to substantiate the fictitious authorship? - into the composition of the second century poetry book; see DingeL 2014.

41 tempus edax in v 1 is an allusion to Ov. met. $15.234 \mathrm{ff}$., to which famous passage there are close factual and literal parallels throughout the poem: e. g. v 2 cf. met. 15.259 f.: nil equidem durare diu sub imagine eadem / crediderim; v 3 cf. met. 15.263 f.: vidi factas ex aequore terras, / et procul a pelago conchae iacuere marinae; v 4 cf. met. 267 : eluvie mons est deductus in aequor; v 5 f. cf. met. 1.256-258 esse quoque in fatis (!) reminiscitur (scil. Iuppiter) adfore tempus, / quo mare, quo tellus correptaque regia caeli / ardeat et mundi moles operosa laboret. For further discussion of the reception of Ovid, see Breitenbach 2010, 19 f. and Breitenbach 2009, 19 f. and 20-24 passim. 
ently existing cosmos (hic mundus, v 8) is subject. The recognition of the unalterable course of events and the readjustment of norms (v 5), i. e. an intellectual act of reconsideration, makes it possible for the poet to incorporate his own experience and supposed misfortunes (originally sentenced to death, Seneca was pardoned to exile) into the larger, cosmic context, and to reevaluate them as a general and therefore less oppressing fact of life. It is hardly a coincidence that, in an etymologizing word play, death (perire) is characterized as mere passing (per-ire) which is devoid of any fear. ${ }^{42}$ Since the same thought occurs in other prose texts of this and later periods, ${ }^{43}$ it may indeed have been a comfort to Seneca in his exile: se non è vero, è ben trovato.

$I X$.

passage within the Consolatio ad Helviam matrem reads almost like a prose version
of the epigram, with Seneca in ipsa persona addressing himself in the same gesture of
consoling encouragement: "if you regard the end of your days, not as a punishment, but as an ordinance of nature, when once you have cast from your breast the fear of death, the fear of no other thing will dare to enter in" ${ }^{44}$. The Consolatio ad Helviam matrem, one of three consolatory texts written in exile, with which Seneca tries to help his mother get over her son's exile (although he himself is of course the one who suffers) by presenting multiple philosophical arguments, discusses fatum (as do the two other consolationes), by comparison with other ethical texts of his, fairly thoroughly. ${ }^{45}$ However, the at first obvious assumption that Seneca sought and found exoneration from personal responsibility and an explanation for his misfortunes in the unavoidable course of fate is not confirmed. Such simple fatalism, which makes use of the powerlessness of man for consolatory purposes - "no one, not even I, bears responsibility for my exile: it is the will of fatum" - does not occur. Let me highlight three aspects that fundamentally cover the use of both the term and the concept of fatum within the Consolatio.

In some instances, we find Seneca employing the concept of fatum - in the technical sense of Stoic heimarmene - as an argument; these are instances where the focus is on a logically coherent argumentation, e. g. in chapter 6 , where he argues that a seemingly grave aspect of his exile, the changing of places from Rome to Corsica, is not a malum, since in the macrocosm, too, we find constant changes of places, of the sun, of the stars, etc.; indeed the very cosmos is, he says, in perpetual motion:

42 In contrast with Dingel 2007, 102 ad loc.

43 Close in wording is the beginning of De remediis fortuitorum: Morieris. Ista hominis natura, non poena est (rem. fort. 1.1). Its authenticity has been under debate since the $17^{\text {th }}$ century. NEwMAN 1988, has recently attempted to prove the authenticity, pointing out the multiple affinities with Seneca's philosophical writings in his commentary. The motif is used for consolation in the Consolatio ad Marciam 10.5: Si mortuum tibi flium doles, eius temporis quo natus est crimen est; mors enim illi denuntiata nascenti est; in hanc legem genitus <est>, hoc illum fatum ab utero statim prosequebatur.

44 Helv. 13.2: si ultimum diem non quasi poenam sed quasi naturae legem aspicis, ex quo pectore metum mortis eieceris, in id nullius rei timor audebit intrare.

45 On the Consolatio ad Helviam see ABel 1967, 47-69. A recent commentary is lacking, therefore FAVEz 1918 and Meinel 1972, are still to be consulted. Giancotti 1957, 74-92, considers it impossible to date the work to so narrow a time window as the period of exile; ABEL 1985, 707, confidently dates it to the first months of exile AD 42 which seems to be the communis opinio, see SAUER 2014, 171. 
All the planets are ever whirling on and passing by; as the inviolable law of Nature has decreed, they are swept from one position to another; when in the course of fixed periods of years they have rounded out their circuits, they will enter again upon the paths by which they came. What folly, then, to think that the human mind, which has been formed from the self-same elements as these divine beings, is troubled by journeying and changing its home, while God's nature finds delight or, if you will, its preservation in continuous and most speedy movement ${ }^{46}$

As in the epigram, consolation is derived from the intellectual cognition of the cosmic law, which is valid in both microcosm and macrocosm, and which allows people to cope with their personal fate intellectually. In much the same way does recognition of the good order serve as consolation in chapter 8 . Fate, the unchangeable chain of causes linked with each other (fatum et inmutabilis causarum inter se cohaerentium series, Helv. 8.3), guarantees that people, wherever they may be, cannot lose what is most important for them: their share in common nature and their personal virtus, which ensures their inner freedom. Becoming aware of this leads straight to gratitude towards heimarmene:

For how little it is that we have lost! Wherever we betake ourselves, two things that are most admirable will go with us - universal Nature and our own virtue. Believe me, this was the intention of the great creator of the universe, whoever he may be, whether an all-powerful God, or incorporeal Reason contriving vast works, or divine Spirit pervading all things from the smallest to the greatest with uniform energy, or Fate and an unalterable sequence of causes clinging one to the other, this, I say, was his intention, that only the most worthless of our possessions should fall under the control of another. ${ }^{47}$

Recognition or ignorance of the well-ordered cosmos decides about subjective happiness. In this way, everybody is indeed responsible for their own fate (unusquisque facere se beatum potest, Helv. 5.1), and can in fact raise themselves through intellectual activity above all adversity to the contemplation of the world as ordered by fatum, which constitutes the greatest happiness. This is exactly what Seneca does in his Corsican exile, as he reassuringly writes to his mother at the climactic end of the consolatio, and we will not be free to see it as a mere phrase, but will have to regard it as an earnest attempt at intellectual autosuggestion, regardless of how successful it actually was:

Indeed, they are now best, since my mind, free from all other engrossment, has leisure for its own tasks, and now finds joy in lighter studies, now, being eager for the truth, mounts to the consideration of its own nature and the nature of the universe. It seeks

46 Helv. 6.8: Omnia uoluuntur semper et in transitu sunt; ut lex et naturae necessitas ordinauit, aliunde alio deferuntur; cum per certa annorum spatia orbes suos explicuerint, iterum ibunt per quae uenerant: $i$ nunc et humanum animum, ex isdem quibus diuina constant seminibus compositum, moleste ferre transitum ac migrationem puta, cum dei natura adsidua et citatissima commutatione uel delectet se uel conservet.

47 Helv. 8.2 f.: Quantulum enim est quod perdimus! duo quae pulcherrima sunt quocumque nos mouerimus sequentur, natura communis et propria uirtus. Id actum est, mihi crede, ab illo, quisquis formator uniuersi fuit, siue ille deus est potens omnium, siue incorporalis ratio ingentium operum artifex, sive diuinus spiritus per omnia maxima ac minima aequali intentione diffusus, siue fatum et inmutabilis causarum inter se cohaerentium series - id, inquam, actum est ut in alienum arbitrium nisi uilissima quaeque non caderent. 
knowledge, first, of the lands and where they lie, then of the laws that govern the encompassing sea with its alternations of ebb and flow. Then it takes ken of all the expanse, charged with terrors, that lies between heaven and earth - this nearer space, disturbed by thunder, lightning, blasts of winds, and the downfall of rain and snow and hail. Finally, having traversed the lower spaces, it bursts through to the heights above, and there enjoys the noblest spectacle of things divine, and, mindful of its own immortality, it proceeds to all that has been and will ever be throughout the ages of all time. ${ }^{48}$

Apart from its function as heimarmene, fatum occurs in the Consolatio ad Helviam to denote in numerous exempla narratives the personal fate of men and women, Romans and Greeks, who have been exposed to various misfortunes and have borne them with fortitude. With all these narratives, Seneca, illustrating to his mother and to himself what really matters, attempts to reassure her and to take comfort himself. The theory, which he expounded in De providentia in a general way, of the didactic function of misfortunes that are sent by fatum to the good and strong in order that they may overcome them and serve as exempla to others, is applied here to his own particular situation:

Cornelia bore twelve children, but Fortune had reduced their number to two; if you wished to count Cornelia's losses, she had lost ten, if to appraise them, she had lost the two Gracchi. Nevertheless, when her friends were weeping around her and cursing her fate, she forbade them to make any indictment against Fortune, since it was Fortune who had allowed the Gracchi to be her sons. ${ }^{49}$

The same striking pairing of fatum and fortuna as in the passage just cited features prominently in the only passage within the treatise, in which fatum - used here, too, like in Cornelia's case, in the sense of 'individual fate' - denotes something negative. Seneca's mother had left home three days before her son was arrested unexpectedly, sentenced to exile, and deported immediately, with no opportunity left for bidding farewell and the last three days they might have had together taken from them by this whim of fortune:

For Fortune cruelly contrived to deal you even this blow - she willed that you should part from me only two days before I was struck down, and you had no reason for concern nor any fear of such a disaster. It is well that we had been separated before by a great distance, it is well that an absence of several years had prepared you for this misfortune. By returning to Rome, you failed to gain the pleasure of seeing your son, and lost the habit of doing without him. Had you been absent long before, you could have borne my misfortune more bravely, since separation itself lessens our longing; had you not gone away, you would have at least gained the final pleasure of seeing your son two days longer. As

48 Helv. $20.1 \mathrm{f}$.: Sunt enim optimae (scil. res meae), quoniam animus omnis occupationis expers operibus suis uacat et modo se leuioribus studiis oblectat, modo ad considerandam suam uniuersique naturam ueri auidus insurgit. Terras primum situmque earum quaerit, deinde condicionem circumfusi maris cursusque eius alternos et recursus; tunc quidquid inter caelum terrasque plenum formidinis interiacet perspicit et hoc tonitribus fulminibus uentorum flatibus ac nimborum niuisque et grandinis iactu tumultuosum spatium; tum peragratis humilioribus ad summa perrumpit et pulcherrimo diuinorum spectaculo fruitur, aeternitatis suae memor in omne quod fuit futurumque est uadit omnibus saeculis.

49 Helv. 16.6: Corneliam ex duodecim liberis ad duos fortuna redegerat: si numerare funera Corneliae uelles, amiserat decem, si aestimare, amiserat Gracchos. Flentibus tamen circa se et fatum eius execrantibus interdixit ne fortunam accusarent, quae sibi filios Gracchos dedisset. 
it was, cruel Fate contrived that you should neither be with me in the midst of disaster, nor have grown accustomed to my absence. But the harder these circumstances are, the more courage must you summon, and you must engage with Fortune the more fiercely, as with an enemy well known and often conquered before. ${ }^{50}$

The account of this blow, which made the exile of her son so much harder for his mother to bear, is framed by two short main clauses which emphasise the cruelty of fate (hoc quoque aduersus te crudeliter fortuna molita est / nunc crudele fatum ita composuit). The parallel construction shows that the two terms fortuna and fatum are meant to be equivalent and interchangeable in this instance. Such an untechnical use of the word, which is otherwise found particularly often in the tragedies, may be accounted for by the fact that the singular, fatum, can denote not only the principle of heimarmene, but also one or other of all the individual fata contained in the cosmic plan, which may subjectively (fortuna crudelis) or even objectively (fatum crudele) be hard to bear. What is important is the consequence that Seneca draws from the cruelty of fate: not to surrender, but to fight, and to overcome it. Not only the imagery of war, but also the idea of continual trials (cum hoste noto ac saepe iam victo congrediendum) and the reinterpretation of mala as a field where to prove, where to exhibit one's virtus, cohere with the theory expounded much later in De providentia and allow the conclusion that Seneca had already early on adopted a firm position on the subject.

$X$

\footnotetext{
eneca once more returned to speaking of the cruelty of fate in the Consolatio, in the prayer he says for his nephew Lucan: "I pray the gods that we may have the good fortune (contingat) to die before he does! May all the cruelty of Fate (fatorum crudelitas) be exhausted and stop at me!" ${ }^{1}$ Now, cruelty counts among the characteristics of unlawful rule, crudelis being the standard epithet of the tyrant. This leads us back to the question of human freedom, which was left open in the Naturales quaestiones. Seneca addressed it e. g. in letter 107 to Lucilius, which contains the famous version of Cleanthes' Stoic hymn: ducunt volentem fata, nolentem trahunt (epist. 107.11). ${ }^{52}$ We will now at least touch on a passage from De vita beata, ${ }^{53}$ where the hymn is alluded to and where Seneca, rejecting the Epicurean model, expounds with ardour and in rhetorically pointed fashion his own position on fatum from an ethical point of view:
}

50 Helv. 15.2-4: Nam hoc quoque aduersus te crudeliter fortuna molita est, quod te ante tertium demum diem quam perculsus sum securam nec quicquam tale metuentem digredi uoluit. Bene nos longinquitas locorum diuiserat, bene aliquot annorum absentia huic te malo praeparauerat: redisti, non ut uoluptatem ex flio perciperes, sed ut consuetudinem desiderii perderes. Si multo ante afuisses, fortius tulisses, ipso interuallo desiderium molliente; si non recessisses, ultimum certe fructum biduo diutius uidendi flium tulisses: nunc crudele fatum ita composuit ut nec fortunae meae interesses nec absentiae adsuesceres. Sed quanto ista duriora sunt, tanto maior tibi uirtus aduocanda est, et uelut cum hoste noto ac saepe iam uicto acrius congrediendum.

51 Helv. 18.6: Deos oro, contingat hunc habere nobis superstitem! In me omnis fatorum crudelitas lassata consistat. Note the plural form fatorum.

52 On letter 107, Seneca's version of the Cleanthes hymn and Cleanthes himself, cf. Wildberger 2006, 294-300; Meijer 2007, and, recently, the brief discussion in Fischer 2008, 202-204. On this important letter, cf. also LEFÈvre 1983, and BeCK 2006.

53 Giancotti 1957, 310-362, dates the treatise to between AD 54 and 62. 
How is such a man able to obey God and to receive in cheerful spirit whatever happens, and, interpreting his mishaps (casuum) indulgently, never to complain of Fate (fato), if he is agitated by the petty prickings of pleasure and pain? But he is not even a good guardian or avenger of his country, nor a defender of his friends if he has a leaning toward pleasures. Therefore let the highest good mount to a place from which no force can drag it down, where neither pain nor hope nor fear finds access, nor does any other thing that can lower the authority of the highest good; but Virtue alone is able to mount to that height. We must follow her footsteps to find that ascent easy; bravely will she stand, and she will endure whatever happens, not only patiently, but even gladly; she will know that every hardship that time brings comes by a law of Nature, and like a good soldier she will submit to wounds, she counts her scars, and, pierced by darts, as she dies she will love him for whose sake she falls - her commander; she will keep in mind that old injunction, "Follow God!" But whoever complains and weeps and moans, is compelled by force to obey commands, and, even though he is unwilling, is rushed none the less to the bidden tasks. But what madness to prefer to be dragged rather than to follow! As much so, in all faith, as it is great folly and ignorance of one's lot to grieve because of some lack or some rather bitter happening, and in like manner to be surprised or indignant at those ills that befall the good no less than the bad - I mean sickness and death and infirmities and all the other unexpected ills that invade human life. All that the very constitution of the universe obliges us to suffer, must be borne with high courage. This is the sacred obligation by which we are bound - to submit to the human lot, and not to be disquieted by those things which we have no power to avoid. We have been born under a monarchy; to obey God is freedom. ${ }^{54}$

The paradoxical aphorism in which the passage culminates - in regno nati sumus: deo parere libertas est - states that the Stoic god, while an equally absolute sovereign, is not a tyrant, but a good ruler. To take exception to this fact, with which our human existence (nati sumus) is inseparably tied up with - for without god's cosmic plan man would not even exist -, would be unreasonable. If, however, man accepts the fact that fatum has unrestricted power, he becomes free to want what is right - which, if it really is right, needs to accord with fatum - and thus to do readily that which is inevitable anyway.

While the passage clearly shows that Seneca fundamentally believes in the freedom of judgement, the problem of freedom of action and thus of responsibility remains unsolved here, too, even though Seneca demands active commitment to country and friends. After examining

54 Vit. beat. 15.4-7: Quomodo hic potest deo parere et quidquid euenit bono animo excipere nec de fato queri casuum suorum benignus interpres, si ad uoluptatum dolorumque punctiunculas concutitur? Sed ne patriae quidem bonus tutor aut uindex est nec amicorum propugnator, si ad uoluptates uergit. Illo ergo summum bonum escendat unde nulla ui detrahitur, quo neque dolori neque spei nec timori sit aditus nec ulli rei quae deterius summi boni ius faciat; escendere autem illo sola uirtus potest. Illius gradu cliuus iste frangendus est; illa fortiter stabit et quidquid euenerit feret non patiens tantum sed etiam uolens, omnemque temporum difficultatem sciet legem esse naturae et ut bonus miles feret uulnera, numerabit cicatrices, et transuerberatus telis moriens amabit eum pro quo cadet imperatorem; habebit illud in animo uetus praeceptum: deum sequere. Quisquis autem queritur et plorat et gemit, imperata facere ui cogitur et inuitus rapitur ad iussa nihilominus. Quae autem dementia est potius trahi quam sequi! tam mehercules quam stultitia et ignoratio condicionis est suae dolere quo deest aliquid tibi aut incidit durius, aeque mirari aut indigne ferre ea quae tam bonis accidunt quam malis, morbos dico, funera, debilitates et cetera ex transuerso in uitam humanam incurrentia. Quidquid ex uniuersi constitutione patiendum est, magno suscipiatur animo: ad hoc sacramentum adacti sumus, ferre mortalia nec perturbari iis quae uitare non est nostrae potestatis. In regno nati sumus: deo parere libertas est. For a detailed commentary on the passage see KuEN 1994, 202-212. 
the Stoic teachings, Gould soberly states: "The Stoic conception of fate is one with which the notion of human responsibility is incompatible" 55 , although, he says, it does credit to the Stoics that they attempted the impossible balancing act: "And it may have been some comfort to realize (as perhaps some of them did) that it is exceedingly difficult not to run into an impasse when trying to give a theoretical account of human responsibility. Is it possible at all to give such an account? If it is, neither hard determinists, soft determinists, simple indeterminists, nor agency theorists (for example, Aristotle) have shown it to be so. If, then, the Stoics suffer embarrassment in this regard, they are hardly alone." ${ }^{56}$

$X I$.

The step-by-step introduction to and training in Stoic theory and practice, which Seneca offers in his late masterpiece, the Epistulae morales, continually refers to fatum; ${ }^{57}$ however, it does not play any role yet in the "elementary course", the cycle of the first twelve letters. Therefore, let me only pick out here epist. 16, where for the first time it occurs more massively. In this letter Seneca calls on Lucilius to understand his philosophical studies, which constitute the only pathway to true happiness, not as a purely theoretical undertaking, but as an eminently practical task, and to persevere in applying those principles that are found right in daily life until they become a habit. ${ }^{58}$ This plea marks the first and the third part of the letter (16.1-3 and 16.6b-9). In between (16.4-6a), Seneca discusses the possible objection of a fictus interlocutor against practising philosophy, who employs a Stoic tenet, determinism, to support his argument. One can hardly fail to recognise the Lazy Argument in rudimentary form behind his words.

Perhaps someone will say: "How can philosophy help me, if Fate (fatum) exists? Of what avail is philosophy if God rules the universe? Of what avail is it, if Chance (casus) governs everything? For not only is it impossible to change things that are determined, but it is also impossible to plan beforehand against what is undetermined; either God has forestalled my plans, and decided what I am to do, or else Fortune (fortuna) gives no free play to my plans." Whether the truth, Lucilius, lies in one or in all of these views, we must be philosophers; whether Fate (fata) binds us down by an inexorable law, or whether God as arbiter of the universe has arranged everything, or whether Chance (casus) drives and tosses human affairs without method, philosophy ought to be our defence. She will encourage us to obey God cheerfully, but Fortune (fortunae) defiantly; she will teach us to follow God and endure Chance (casum). But it is not my purpose now to be led into a discussion as to what is within our own control, - if foreknowledge is supreme, or if a chain of fated events drags us along in its clutches, or if the sudden and the unexpected play the tyrant over us." ${ }^{\circ 9}$

55 Gould 1974, 32. On Stoic attempts to uphold human responsibility, cf. the literature listed above n. 31.

56 Gould 1974, 32.

57 A number of striking passages are discussed in Andreoni Fontecedro 1992, 165-170. On the particularly important letter 107, cf. n. 52 above.

58 Epist. 16.1: Perseverandum est et assiduo studio robur addendum, donec bona mens sit quod bona voluntas est; $16.6 \mathrm{~b}$ impetum animi tui ... contine ... et constitue, ut habitus animi flat quod est impetus.

59 Epist. 16.4-6: Dicet aliquis, 'quid mihi prodest philosophia, si fatum est? quid prodest, si deus rector est? quid prodest, 
Three instances, an impersonal fate (fatum), a personal cosmic ruler (deus), and chance (casus/fortuna), are discussed. The critic claims that in either case it is pointless to practise philosophy and to strive after the philosophically well-led life, i. e. to be active. Seneca objects. Insofar as the first two coincide with regard to their effect (fatum) or possible implication (deus), i. e. the complete determination of human life, Seneca, following Stoic practice, can treat them as being interchangeable, even essentially identical, and discuss them both at the same time. ${ }^{60}$ By speaking of them in terms of legitimate rule, they are interpreted as much more positive forces (imperium, rector, lex) than tyrannical chance (dominari). However, Seneca does not outright reject chance - the concept that at first glance would be associated with Epicurean doctrine, but gives it serious consideration and even concedes the possibility that it need not form an irreconcilable contrast to fate (vel si omnia haec sunt). In fact, it seems that in Seneca's eyes it may well have been possible to harmonise the two principles, if one takes casus/fortuna as the restricted human outside perspective on an internally determined course of events. ${ }^{61}$

The ideal recipient, who, upon reading the letter, has reached the same level of reflection as Lucilius, cannot be completely aware of this yet. The passage is indeed rather typical of the cautious approach to philosophical questions in the Epistulae morales. An abundance of termini technici are introduced without any clear terminological distinction (fatum, fortuna, casus, providentia, iuris nostri esse); well-known loci are referred to, such as the catchphrase deum sequere (cf. ut deum sequaris) or the aphorism ducunt volentem fata, nolentem trahunt (cf. si fatorum series inligatos trahit); farther-reaching motifs are alluded to, such as the cosmic reason and justice of the supreme governor (cf. arbiter ... universi cuncta disposuit), the proven ability to resist (apparent) misfortunes (cf. pareamus ... fortunae contumaciter) or the paradox of liberating obedience (cf. deo libenter pareamus). All of this serves to hint at the depth of the problem discussed, and to prepare for future instruction, as well as to demonstrate the philosophical competence of the speaker.

Seneca's reply to the striking objection seems to be just as striking. Against the simple argument, "if everything is mere chance or determined by fate, I need not even try to act, since everything will be happening anyway the way happens", he upholds the positive and therefore desirable outcome of studying philosophy, which helps to endure the vicissitudes of fortune, which otherwise are hard or impossible to bear, and to see the good sides of fate, to which people otherwise feel helplessly subject. It seems as if Seneca wants to argue for human action only on the level of subjective mental feeling or experiencing. That we are in fact looking at the Lazy Argument in an unusual, and rather refined form, insofar as it is turned against practising (Stoic) philosophy itself, aiming at the Stoic doctrine of fatum, only shows at the end of the paragraph, in the surprising praeteritio of the problem that only just follows from the $\alpha \varrho \gamma$ ò

si casus imperat? Nam et mutari certa non possunt et nihil praeparari potest adversus incerta, sed aut consilium meum occupavit deus decrevitque quid facerem, aut consilio meo nihil fortuna permittit.' Quidquid est ex his, Lucili, vel si omnia haec sunt, philosophandum est; sive nos inexorabili lege fata constringunt, sive arbiter deus universi cuncta disposuit, sive casus res humanas sine ordine inpellit et iactat, philosophia nos tueri debet. Haec adhortabitur ut deo libenter pareamus, ut fortunae contumaciter; haec docebit ut deum sequaris, feras casum. Sed non est nunc in hanc disputationem transeundum, quid sit iuris nostri si providentia in imperio est, aut si fatorum series inligatos trahit, aut si repentina ac subita dominantur...

60 For this approximate identity of fatum and deus, see BaldarotTa 1994, 23, and HaCHMANN 2000, 295.

61 Cf. Hachmann 2000, 295-298. 
$\lambda$ 'ó $\mathrm{OS}$, i. e. the problem of responsibility and accountability within a deterministic system (cf. quid sit iuris nostri si providentia in imperio est). Seneca adjourns the problem without further excuse or specification of Stoic viewpoint.

It shows again that Seneca evidently had a firm opinion of the term fatum in his philosophical writings. The solid basis and a core element of Stoic self-understanding, he employs it, as we have seen, to explain, to console, to comfort. Seneca is aware that the Stoic conception of fatum is unpopular with many of his contemporaries, and he openly deals with the problem time and again, as in epist. 16. But nowhere do we find a maceration or attenuation of the Stoic position. Seneca does not even offer a fundamental discussion of the term, as Cicero so brilliantly had done in his De fato.

$X I I$.

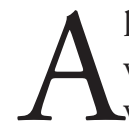
Imost everything about Seneca's tragedies is under debate. This includes the questions whether they are at all intended to make a philosophical statement, and, if they are, whether this statement agrees with the Stoic doctrines as expounded in his prose works, and, if this is not the case, how the discrepancies are to be explained: as a tribute to generic conventions and poetic diction, as conscious negation or even palinode of his own teachings, as a continuation of philosophy on ground hitherto uncovered? A focal point of the discussion regularly is Seneca's portrayal of the gods: is e. g. the representation of Juno, who, in the prologue of the Hercules furens, laments her impotence and decides to take revenge on the hero, the conqueror of the terrors of Hades, by driving him to madness and despair, compatible with the Stoic conception of god? ${ }^{62}$ It may well be impossible to ever wrest a clear answer from these eminently poetic and open texts. However, the more recent debate shows that the question is worth asking over and over again for that reason alone that it leads to a deeper understanding of Seneca's notion of the tragic as well as of his philosophical thinking. A case in point is Christine Schmitz' discussion of the 'cosmic dimension' in the tragedies; with regard to the Hercules furens she comes to the conclusion that the interpretatory model according to which the appearance of Juno is nothing but an outside projection of Hercules' inner processes, i. e. nothing but the dramatic enactment of Stoic psychology, is ultimately inadequate. ${ }^{63}$ Claudia Wiener shows that the tragedies, while not simple didactic plays, can nevertheless be read Stoically, in the sense that the discourse begun in the philosophical works is continued in the plays, employing a terminology that is compatible with that of the

62 For an overview of the more recent interpretations of Hercules furens, see Billerbeck, Guex 2002, 25-29 and Billerbeck 2014, 428-430, for a new comprehensive interpretation, see EIsGrub 2003. The articles collected in BAIER 2012, are concerned exclusively with post-Virgilian conceptions of fatum in epic poetry; to compare these with the one developed in Seneca's tragedies seems well worth making the effort. For a broad access to the topic, see FISCHER 2014.

63 Cf. Schmitz 1993, 127-131. Discussing Rosenmeyer 1989, esp. 63-90, who recognises in the tragedies the evolution of a pessimistic cosmology as counterpoise to the optimism of the prose writings, SCHMITz 1993, 7-13, warns against being too quick to read utterances of individual dramatis personae as general philosophical statements. But then again, it is neither possible to divorce these utterances altogether from philosophy by pointing out their poetic-symbolical character, as Lefèvre 1995, does (with regard to the presentation of the gods in the tragedies), nor to harmonise statements found in the prose writings and in the tragedies too easily with each other, as BALDAROTTA 1994, 28, tends to do. 
prose writings, although not necessarily yielding the same results; while the failures of the protagonists or their counsellors in plays such as Agamemnon, Medea, Phaedra or Thyestes can be harmonised with Stoic psychology and the doctrine of passions, in the other plays - like e. g. the Hercules furens - the tragic action stems not from an intrinsically motivated act of will, but is influenced by fatum-fortuna, without the question of moral guilt being finally answered or even intended to be answered:

„Die 'belletristischen' Werke des Stoikers Seneca und Lucans historisches Epos sind bis in die Grundaussagen hinein von den Problemstellungen der Stoa durchdrungen; da sie die stoische Moraldidaxe nicht plakativ zur Schau stellen, sondern die psychologischen Kenntnisse gerade zu einer differenzierten, lebensechten und nie schematisch wirkenden Figurenkonzeption einsetzen, kann es bei modernen Interpretationsansätzen zu Deutungen kommen, die die schon in der Antike kritisierte Problematik der menschlichen Willensfreiheit und des kausalen Determinismus als Absage an die Lehre der Stoa verstehen. Hier wird zu zeigen sein, daß sich beide Autoren gerade insofern als typisch stoische Literaten erweisen, als sie nicht simplifizierend einen guten Gott in der besten aller Welten predigen, der persönlich jeden Menschen vor Schicksalsschlägen zu bewahren habe, sondern daß er dem Menschen innerhalb des festbestimmten Kreislaufs von Werden und Vergehen die Möglichkeit moralisch guten Handelns eröffnen muß. Seneca und Lucan stellen sich beide dem schwierigsten Problem, mit dem sich die Stoa seit der Gründergeneration auseinandersetzen mußte, und nutzen zu ihrer (sic!) Beantwortung das Drama als psychologisches Experimentierfeld und das Epos als Schaubühne des Welttheaters, auf dem die Figuren beinahe unerträglichen Krisensituationen ausgesetzt sind - dem kritischen Beobachter bleibt dann die Bewertung der verschiedensten Verhaltensmöglichkeiten in diesen Bewährungsproben und die Konsequenz aus dieser Erkenntnis eigenverantwortlich überlassen: als eine intellektuell anspruchsvolle Art stoischer Moraldidaxe." ${ }^{64}$

In the latest contribution on Seneca the "theologian", Susanna Fischer takes as her starting point the understanding of providentia and fatum in the philosophical writings to measure against them the remarks of the dramatic figures about (their) fate. She comes to the conclusion that the tragedies, while picking up from the teachings of the prose writings, actually point beyond them in content, leading, especially with regard to the problem of theodicy, to aporias that are intrinsic to Stoicism. She focusses on the figure of Juno, who, in the prologue of the Hercules furens, complains about her husband's lovers and children, all newly transformed into stars, ousting her from heaven, and vows to take revenge on his latest mistress, Alcmene, and her son Hercules. Failing in her attempts to find some other dangerous monster to obstruct his way from hero to god since he has already overthrown them all, she hits on the idea that he should destroy himself, to which end she evokes the furies, discordia, scelus, impietas, error and furor. And during the main dramatic action Hercules indeed goes insane, defies the gods in impious speech, and in a frenzy of rage erroneously commits a horrid crime, killing his own wife and children. ${ }^{65}$ Fischer, too, sees Juno as a power which effects what happens to Hercules from without, and, by identifying intratextual references to the main dramatic action and

64 WiENER 2006, 17.

65 Cf. Fischer 2008, 57-91, with an extensive discussion of the prologue of the Hercules furens, including previously suggested interpretations. 
intertextual ones to Seneca's philosophy, proves that Juno carries the most characteristic traits of fortuna, that she reads in fact almost as an allegory of it, with which Hercules the "Stoic" battles successfully before and afterwards, yet in vain here; it is only at the end of the play that in accepting his guilt he proves his greatness: „Die mythische Gestalt des Hercules verbildlicht die Gottähnlichkeit des Menschen und das Streben nach dem Göttlichen (...). Im Zweikampf mit fortuna wird seine virtus auf die Probe gestellt. Auch wenn Hercules am Ende nicht aus Einsicht handelt, erträgt er doch mit patientia das Bewusstsein seiner subjektiven Schuld. Indem Hercules durch sein Unglück auf die Probe gestellt wird, löst sich in diesem Drama die Theodizeefrage im Sinne von Senecas philosophischer Schrift De providentia."66

In continuance of this position, in which Juno-Fortuna is somewhat too smoothly integrated into Stoic thinking, one might consider regarding the deity as a radicalised form of the concept of fortuna. While the mala, with which (supposedly blind) fortune maltreats humans, are usually that which is (supposedly) bad, Juno, here, is downright evil; and the abysmal evil, which leaves even villains such as Tantalus horrified, dominates other plays, too, above all the Thyestes. Juno, the worse half of Jupiter, could then be a superhuman image of the spirit that always wills evil without being able to prevent good in the end, in fact rather helping it come about, ${ }^{67}$ thus showing Seneca's struggle with a systematic gap in his philosophy: for evil, its origin and its end have no place within Stoic thinking. To come to a conclusion here nevertheless, Seneca might have used the tragedies also to express in indirect language and by poetic means what could not have been said in philosophic discourse. As such, they would be structurally comparable with the Platonic myths, which also do not contain contradictions to philosophical positions, but describe that which goes beyond philosophy itself.

In conclusion, Seneca's remarks on fatum, as far as they occur within explicitly philosophical discourse, altogether prove to be consistent within themselves and surprisingly constant throughout his entire oeuvre. Following Stoic tradition as known to him, he unequivocally recognises an essentially impersonal, yet active, universal, purposeful, and benign providence, which the individual cannot escape, only reject to their detriment or accept for their own good. The latter Seneca judges to be liberating and comforting, and he strives to apply this principle in his own life. It is a strange fact that a doctrine that was supposed to promote fatalism and submission to an all-pervading, all-powerful fate, and that was meant to lead people, by continual exhortations, to contemplation and retreat in order to focus on their inner selves, produced the opposite effect in imperial times. Seneca himself was not stopped by his adherence to Stoicism from actively participating in politics and from continually seeking publicity for his writings. The Roman senatorial aristocracy partly emphatically opted for Stoicism, they were heavily influenced by it, and none other than the Stoics led the opposition against the emperor not only with words, but also by armed rebellion. The sympathies of the aristocracy for a philosophy that was easy to accommodate to traditional Roman morality and to give

66 Fischer 2008, 91. Hachmann, Der fortuna-Begriff, 304-318, has plausibly shown for the Epistulae morales that Seneca for didactic reasons indeed includes popular ideas in order to then gradually overcome them. However, this technique is hardly applicable to tragedy.

67 Juno herself repeatedly (v 23 and 121f.) mentions that it is Hercules' destiny to ascend to the realm of the gods, which she, as myth tells, cannot prevent; rather, setting him the task of expiating the horrible deed, she even creates a new opportunity for Hercules to prove himself, like she has always helped him before in his quest - as she herself admits (v 33-35) - by setting him the different labours. 
strength, owing to its elitist nature and systematic coherence, to a social group that saw a steady decline in political influence during the Principate, are readily comprehensible. What remains a mystery is why this philosophy of all should have freed its adherents to act.

Christoph Schubert Bergische Universität Wuppertal Fachbereich A Klassische Philologie / Latein Gaußstr. 20 D - 42119 Wuppertal schubert@uni-wuppertal.de

\section{Bibliography}

\section{Editions and Commentaries}

Billerbeck, Guex 2002

M. Billerbeck, S. Guex (eds.), Sénèque, Hercule furieux, Sapheneia 7, Bern 2002.

BReitenbach 2009

A. Breitenbach, Kommentar zu den Pseudo-SenecaEpigrammen der Anthologia Vossiana, Anthologiarum Latinarum Parerga II, Hildesheim 2009.

BREITENBACH 2010

A. Breitenbach (ed.), Die Pseudo-Seneca-Epigramme der Anthologia Vossiana: ein Gedichtbuch aus der mittleren Kaiserzeit, Spudasmata 132, Hildesheim et al. 2010.

\section{Dingel 2007}

J. Dingel, Senecas Epigramme und andere Gedichte aus der Anthologia Latina, Wissenschaftliche Kommentare zu griechischen und lateinischen Schriftstellern, Heidelberg 2007.

FAVEz 1918

Ch. Favez (ed.), L. Annaei Senecae dialogorum liber XII ad Helviam matrem de consolatione. Texte latin publié avec une introduction et un commentaire explicatif, Diss. Lausanne 1918.

FINK 1992

G. Fink (ed.), L. Annaeus Seneca, Die kleinen Dialoge, 2 Vols., München - Zurich 1992.

\section{HAASE 1853}

F. Haase (ed.), L. Annaei Senecae opera quae supersunt, Vol. III, Leipzig 1853.

Hine 1996 a

H.M. Hine (ed.), L. Annaei Senecae naturalium quaestionum libros, Stuttgart - Leipzig 1996.

\section{Hine 1981}

H.M. Hine, An Edition with Commentary of Seneca, Natural Questions, Book Two, Monographs in Classical Studies, Salem, New Hampshire 1981.

Kuen 1994

G. Kuen, Die Philosophie als dux vitae. Die Verknüpfung von Gehalt, Intention und Darstellungsweise im philosophischen Werk Senecas, Wissenschaftliche Kommentare zu griechischen und lateinischen Schriftstellern, Heidelberg 1994.

Newman 1988

R.J. Newman, Lucii Annaei Senecae de remediis fortuitorum liber ad Gallionem fratrem, Diss. microfilm John Hopkins University Baltimore (Maryland) 1988.

Prato 1955

C. Prato (ed.), Gli epigrammi attribuiti a L. A. Seneca, Biblioteca di letterature classiche 3, Bari 1955.

\section{REYNOLDS 1977}

L.D. Reynolds (ed.), L. Annaei Senecae Dialogorum libri duodecim, Oxford 1977.

SCHÖNBERGER, SCHÖNBERGER 1990

O. Schönberger, E. Schönberger (eds.), Lucius Annaeus Seneca, Naturwissenschaftliche Untersuchungen in acht Büchern, Würzburg 1990.

Shackleton Bailey 1982

D.R. Shackleton Bailey (ed.), Anthologia Latina I. Carmina in codicibus scripta. Fasc. 1 Libri Salmasiani aliorumque carmina, Stuttgart 1982. 
Secondary Literature

Abel 1967

K. Abel, Bauformen in Senecas Dialogen: Fünf Strukturanalysen, dial. 6, 11,12, 1 und 2, Heidelberg 1967.

ABel 1985

K. Abel, «Seneca. Leben und Leistung», $A N R W$ II 32,2 (1985), 653-775.

Amand de Mendieta 1945

D. Amand de Mendieta, Fatalisme et liberté dans l'antiquité grecque, Leuven 1945 (ND Amsterdam 1973).

Andreoni Fontecedro 1992

E. Andreoni Fontecedro, «Le espressioni del fato nella scrittura di Seneca filosofo", in La langue latine langue de la philosophie, actes du colloque organisé par l'Ecole française de Rome avec le concours de l'Université de Rome "La Sapienza " (Rome, 17-19 mai 1990), Paris 1992, 161-171 (except for typing errors identical with: Ead., Le espressioni del fato nella scrittura di Seneca filosofo, Aufidus 11-12 (1990), 127-140).

ANWANDER 1948

A. Anwander, "Schicksalswörter in Antike und Christentum", Zeitschrift für Religions- und Geistesgeschichte 1 (1948), 315-327 / 2 (1949/1950), 48-54.

ArNim 1905

H. von Arnim, Die stoische Lehre von Fatum und Willensfreiheit, Wissenschaftliche Beilage zum 18. Jahresbericht der Philosophischen Gesellschaft der Universität Wien 1905.

BAIER 2012

Th. Baier (ed.), Götter und menschliche Willensfreiheit. Von Lucan bis Silius Italicus, Zetemata 142, München 2012.

BALDAROTTA 1994

D. Baldarotta, Fato e volontà in Seneca, Aufidus 23 (1994), 23-33.

BECK 2006

J.-W. Beck, «Senecas 107. Brief: „Sand ohne Kalk“?», Gymnasium 113 (2006), 431-454.

Begemann 2012

E. Begemann, Schicksal als Argument. Ciceros Rede vom fatum in der späten Republik, Potsdamer Altertumswissenschaftliche Beiträge 37, Stuttgart 2012.

Billerbeck 2014

M. Billerbeck, "Hercules furens», in G. Damschen, A. Heil (eds.), Brill's Companion to Seneca, Leiden Boston 2014, 425-433.

BoBZIEN 1998

S. Bobzien, Determinism and Freedom in Stoic Philosophy, Oxford - New York 1998.
BRENNAN 2005

T. Brennan, The Stoic Life. Emotions, Duties, and Fate, Oxford - New York 2005.

Busa, Zampolli 1975

R. Busa, A. Zampolli, Concordantiae Senecanae, 2 vols., Hildesheim - New York 1975.

Damschen, Heil 2014

G. Damschen, A. Heil (eds.), Brill's Companion to Seneca, Leiden - Boston 2014.

Delatte, Evrard, Govaerts, Denooz 1981

L. Delatte, E. Evrard, S. Govaerts, J. Denooz (eds.), Lucius Annaeus Seneca. Opera Philosophica. Index Verborum. Listes de Fréquence. Relevés Grammaticaux, 2 vols., Hildesheim - New York 1981.

Denooz 1980

J. Denooz (ed.), Lucius Annaeus Seneca. Tragoediae. Index Verborum. Relevés Lexicaux et Grammaticaux, Hildesheim - New York 1980.

Dihle 1982

A. Dihle, The Theory of Will in Classical Antiquity, Berkeley, Calif. 1982 (= Id., Die Vorstellung vom Willen in der Antike, Göttingen 1985).

Dingel 2014

J. Dingel, "Epigrams», in G. Damschen, A. Heil (eds.), Brill's Companion to Seneca, Leiden - Boston 2014, 689-694.

EISGRUB 2003

A. Eisgrub, Seneca, Hercules furens. Handlung, Bühnengeschehen, Personen und Deutung, Diss. Würzburg 2003.

Fischer 2008

S.E. Fischer, Seneca als Theologe. Studien zum Verhältnis von Philosophie und Tragödiendichtung, Beiträge zur Altertumskunde 259, Berlin - New York 2008.

Fischer 2014

S.E. Fischer, «Systematic Connections between Seneca's Philosophical Works and Tragedies», in G. Damschen, A. Heil (eds.), Brill's Companion to Seneca, Leiden - Boston 2014, 181-190.

Frede 2011

M. Frede, A Free Will. Origins of the Notion in Ancient Thought, ed. A.A. Long, Sather Classical Lectures 68, Berkeley 2011.

FuHrmann 1997

M. Fuhrmann, Seneca und Kaiser Nero. Eine Biographie, Berlin 1997.

GAMBet 1970

D.G. Gambet, «Cicero in the Works of Seneca philosophus", TAPhA 101 (1970), 171-183. 
Gauly 2004

B.M. Gauly, Senecas Naturales Quaestiones. Naturphilosophie für die römische Kaiserzeit, Zetemata 122, München 2004.

GiancotTi 1957

F. Giancotti, Cronologia dei Dialoghi di Seneca, Torino 1957.

Gould 1974

J.B. Gould, "The Stoic Conception of Fate», Journal of the history of ideas 35 (1974), 17-32.

GRIFFIN 1976

M.T. Griffin, Seneca. A Philosopher in Politics, Oxford 1976.

Grimal 1978

P. Grimal, Seneca. Macht und Ohnmacht des Geistes, Impulse der Forschung 24, Darmstadt 1978.

Grimal 1984

P. Grimal, «Sénèque, juge de Cicéron», MEFR 96 (1984), 655-670.

\section{Gross 1989}

N. Gross, Senecas Naturales Quaestiones. Komposition, Naturphilosophische Aussagen und ihre Quellen, Palingenesia 27, Stuttgart 1989.

Gundel 1912

W. Gundel, s.v. Heimarmene, in RE 7, 2 (1912), 2622-2645.

Gundel 1914

W. Gundel 1914, Beiträge zur Entwicklungsgeschichte der Begriffe Ananke und Heimarmene, Habilschr. Gießen 1914.

HABINEK 2014

TH. Habinek, «Imago suae vitae: Seneca's Life and Careen, in G. Damschen, A. Heil (eds.), Brill's Companion to Seneca, Leiden - Boston 2014, 3-31.

HaCHManN 2000

E. Hachmann, "Der fortuna-Begriff in Senecas Epistulae morales", Gymnasium 107 (2000), 295-319.

Hine 1980

H.M. Hine, "The Manuscript Tradition of Seneca's Natural Questions», Classical Quarterly 30 (1980), 183-217.

Hine 1996 b

H.M. Hine, Studies in the Text of Seneca's Naturales Quaestiones, Beiträge zur Altertumskunde 72, Stuttgart - Leipzig 1996.

INwood 2005

B. Inwood, Reading Seneca. Stoic Philosophy at Rome, Oxford 2005.
INwood 2008

B. Inwood, "The Will in Seneca the Younger», in J.G. Fitch (ed.), Oxford Readings in Classical Studies, Seneca, Oxford 2008, 114-135.

ЈАКові 1988

R. Jakobi, Der Einfluß Ovids auf den Tragiker Seneca, Untersuchungen zur antiken Literatur und Geschichte 28, Berlin - New York 1988.

\section{Kranz 1992}

M. Kranz, s.v. Schicksal, in Historisches Wörterbuch der Philosophie 8 (1992), 1275-1289.

LEFÈVRE 1983

E. Lefevvre, «Der Mensch und das Schicksal in stoischer Sicht. Senecas 51. und 107. Brief", $A U 26$ (1983), 61-73.

LEFÈVRE 1995

E. Lefèvre, «Götter, Schicksal und Handlungsfreiheit in Senecas Tragödien", in B. Kühnert, V. Riedel, R. Gordesiani (eds.), Prinzipat und Kultur im 1. und 2. Jahrhundert, Bonn 1995, 164-185.

Magris 1984/85

A. Magris, L'idea di destino nel pensiero antico: vol. 1 Dalle origini al V secolo A.C.; vol. 2 Da Platone a $S$. Agostino, Udine 1984/85.

Marshall 2014

C.W. Marshall, «The Works of Seneca the Younger and their Dates", in G. Damschen, A. Heil (eds.), Brill's Companion to Seneca, Leiden - Boston 2014, 33-44.

Maso 2013

S. Maso, "Quarundam rerum initia in nostra potestate sunt: Seneca on Decision Making, Fate, and Responsibility", in F.G. Masi, S. Maso (eds.), Fate, Chance, and Fortune in Ancient Thought, Amsterdam 2013, 125-144.

Maso 2014

S. Maso, "La filosofia stoica e la questione del libero arbitrio", in C. Tugnoli (ed.), Libero arbitrio. Teorie e prassi della libertà, Napoli 2014, 157-183.

Maurach 2005

G. Maurach, Seneca. Leben und Werk, Darmstadt 4th ed. 2005.

Mejjer 2007

P.A. Meijer, Stoic Theology: Proofs for the Existence of the Cosmic God and of the Traditional Gods: Including a Commentary on Cleanthes' Hymn on Zeus, Delft 2007.

Meinel 1972

P. Meinel, Seneca über seine Verbannung. Trostschrift an die Mutter Helvia. Mit einem Exkurs: Ducunt volentem fata, nolentem trahunt, Diss. Erlangen, Bonn 1972. 
Moreschini 1977

C. Moreschini, "Cicerone filosofo fonte di Seneca?", RCCM 19 (1977), 527-534.

Мотто 1970

A.L. Motto, Seneca Sourcebook. Guide to the Thought of Lucius Annaeus Seneca in the Extant Prose Works, Amsterdam 1970.

Motto, Clark 1989

A.L. Motto, J.R. Clark (eds.), Seneca. A Critical Bibliography 1900-1980. Scholarship on his Life, Thought, Prose, and Influence, Amsterdam 1989.

Neri 1986

V. Neri, «Dei, fato e divinazione nella letteratura latina del I secolo d.C.", $A N R W$ II 16,3 (1986), 1974-2051.

NIEM 2008

A. Niem, Seneca, De providentia. Ein Kommentar, Norderstedt $2008^{2}$.

Pohlenz 1984/90

M. Pohlenz, Die Stoa, 2 vols., Göttingen 6th ed. 1984 / 1990.

PÖTSCHER 1974

W. Pötscher, «Fatum», Grazer Beiträge 2 (1974), 171187.

PÖTSCHER 1978

W. Pötscher, «Das römische Fatum. Begriff und Verwendung», $A N R W$ II 16,1 (1978), 393-424.

REESOR 1978

M.E. Reesor, "Necessity and Fate in Stoic Philosophy", in J.M. Rist (ed.), The Stoics, Berkeley 1978, 187-202.

ROSENMEYER 1989

TH.G. Rosenmeyer, Senecan Drama and Stoic Cosmology, Berkeley 1989.

RozelaAr 1976

M. Rozelaar, Seneca. Eine Gesamtdarstellung, Amsterdam 1976.

SAUER 2014

J. Sauer, "Consolatio ad Helviam», in G. Damschen, A. Heil (eds.), Brill's Companion to Seneca, Leiden Boston 2014, 171-173.

Schmitz 1993

Chr. Schmitz, Die kosmische Dimension in den Tragödien Senecas, Untersuchungen zur antiken Literatur und Geschichte 39, Berlin - New York 1993.

SCHRÖDER 1969

H.O. Schröder, s.v. Fatum (Heimarmene), RAC 7 (1969), 580-636.
Sсотт 1986

J.M. Scott, The Concepts of fatum and voluntas in the Prose Works of Seneca, University of Washington 1986.

ScOTт Sмiтh 2014

R. Scott Smith, "De providentia», in G. Damschen, A. Heil (eds.), Brill's Companion to Seneca, Leiden Boston 2014, 115-120.

Setaioli 2014

A. Setaiolı, "Ethics III: Free Will and Autonomy», in G. Damschen, A. Heil (eds.), Brill's Companion to Seneca, Leiden - Boston 2014, 277-299.

Sørensen 1984

V. Sørensen, Seneca. Ein Humanist an Neros Hof, München 1984.

STEGEMANN 1939

V. Stegemann, «Fatum und Freiheit im Hellenismus und in der Spätantike», Gymnasium 50 (1939), 165191.

STOK 1995

F. Stok, "I decreti del fato (Seneca, Nat. 2,35,2)», in

I. Gallo (ed.), Seconda miscellanea filologica, Napoli 1995, 105-112.

STOugh 1978

Ch. Stough, «Stoic Determinism», in J.M. Rist (ed.), The Stoics, Berkeley 1978, 202-231.

VAlgiglio 1967/68

E. Valgiglio, "Il fato nel pensiero classico antico", Rivista di studi classici 15 (1967), 305-330 / 16 (1968), 56-84.

VEYNe 1993

P. Veyne, Weisheit und Altruismus. Eine Einführung in die Philosophie Senecas, Frankfurt/Main 1993.

WAIBLINGER 1977

F.P. Waiblinger, Senecas Naturales Quaestiones. Griechische Wissenschaft und römische Form, Zetemata 70, München 1977.

WIENER 2006

C. Wiener, Stoische Doktrin in römischer Belletristik. Das Problem von Entscheidungsfreiheit und Determinismus in Senecas Tragödien und Lucans Pharsalia, Beiträge zur Altertumskunde 226, München - Leipzig 2006.

WiLDBERGER 2006

J. Wildberger, Seneca und die Stoa: Der Platz des Menschen in der Welt, Untersuchungen zur antiken Literatur und Geschichte 84, 2 vols., Berlin - New York 2006. 